\title{
FY 2005 Final Report: Solar Radiometry and Metrology Task PVC57301
}

Technical Report NREL/TP-560-38917

November 2005

D.R. Myers, T.L. Stoffel, A.M. Andreas, S.M. Wilcox, I.M. Reda, M. Anderberg, P. Gotseff, and B.A. Kay National Renewable Energy Laboratory

A. Bowen

School of Engineering and Computer Science Baylor University

Waco, Texas

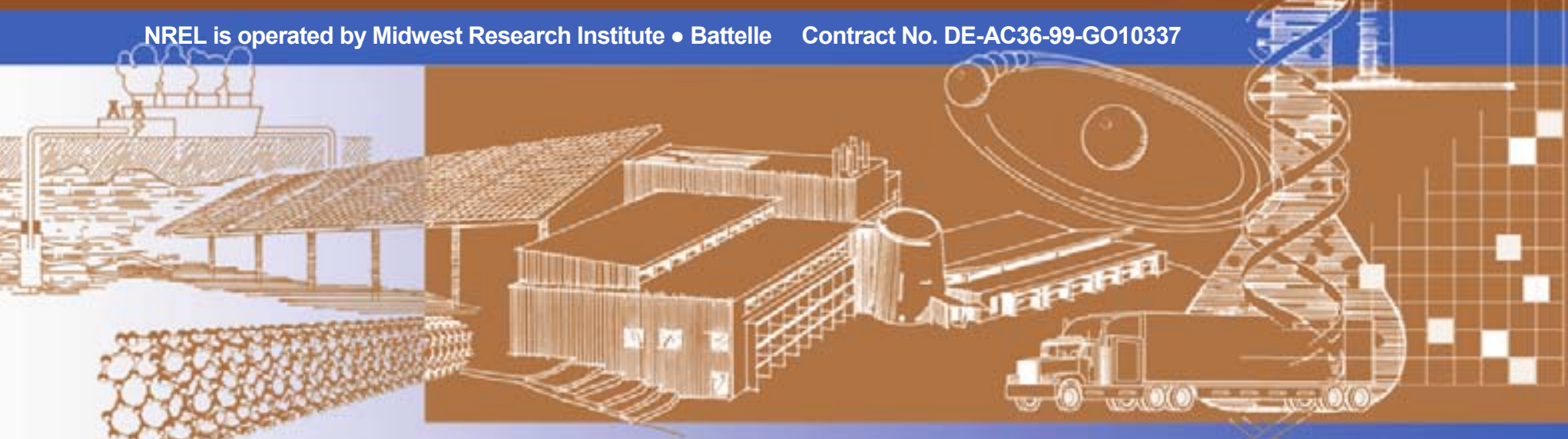


FY 2005 Final Report: Solar Radiometry and Metrology Task PVC57301

Technical Report NREL/TP-560-38917

November 2005

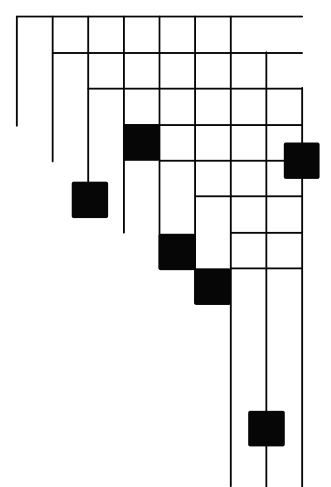

School of Engineering and Computer Science

Baylor University

Waco, Texas

Prepared under Task No. PVC5.7301

National Renewable Energy Laboratory

1617 Cole Boulevard, Golden, Colorado 80401-3393

303-275-3000 • www.nrel.gov

Operated for the U.S. Department of Energy

Office of Energy Efficiency and Renewable Energy

by Midwest Research Institute - Battelle

Contract No. DE-AC36-99-G010337 


\section{NOTICE}

This report was prepared as an account of work sponsored by an agency of the United States government. Neither the United States government nor any agency thereof, nor any of their employees, makes any warranty, express or implied, or assumes any legal liability or responsibility for the accuracy, completeness, or usefulness of any information, apparatus, product, or process disclosed, or represents that its use would not infringe privately owned rights. Reference herein to any specific commercial product, process, or service by trade name, trademark, manufacturer, or otherwise does not necessarily constitute or imply its endorsement, recommendation, or favoring by the United States government or any agency thereof. The views and opinions of authors expressed herein do not necessarily state or reflect those of the United States government or any agency thereof.

Available electronically at http://www.osti.gov/bridge

Available for a processing fee to U.S. Department of Energy and its contractors, in paper, from:

U.S. Department of Energy

Office of Scientific and Technical Information

P.O. Box 62

Oak Ridge, TN 37831-0062

phone: 865.576 .8401

fax: 865.576 .5728

email: mailto:reports@adonis.osti.gov

Available for sale to the public, in paper, from:

U.S. Department of Commerce

National Technical Information Service

5285 Port Royal Road

Springfield, VA 22161

phone: 800.553 .6847

fax: 703.605.6900

email: orders@ntis.fedworld.gov

online ordering: http://www.ntis.gov/ordering.htm 


\section{Preface}

This report documents technical detail for work performed in the Solar Radiometry and Metrology Task PVC57301 in the period from October 12004 to September 302005. The Task has conducted improved broadband and spectral calibrations, measurements, and modeling activities supporting NREL's Photovoltaic Systems Engineering Project, and Photovoltaic Measurements and Characterization Projects. Throughout the entire fiscal year, the task accomplished the following:

- Conducted intercomparison of absolute cavity radiometers to assure the stable maintenance of the World Radiometric Reference at NREL.

- Completed preparations for travel to the World Radiation Data Center, Davos, Switzerland, to transfer the World Radiometric Reference to NREL reference absolute cavity radiometers, in compliance with International Standards Organization ISO standard 17025 requirements for traceability of NREL's solar measurements.

- Calibrated nine spectroradiometer systems used to classify and characterize continuous and pulsed solar simulators for NREL and PV industry partners. These instruments were used to acquire and use data to correct for deviations from standard reporting condition reference spectra.

- Developed specifications for purchasing a new spectrometer to replace obsolete spectroradiometers used in Reference Photovoltaic Cell Calibrations

- Conducted detailed studies of thermal offsets in pyranometers and pyrheliometers; a significant source of measurement error in broadband radiometers measuring total hemispherical and direct beam solar radiation.

- Updated, revised, and submitted for consensus ballot three new standard methods for calibrating broadband solar radiometers for the American Society for Testing and Materials.

- Installed and tested new, more accurate data acquisition system upgrades for broadband radiometer calibrations and successfully integrated them into existing Radiometer Characterization and Calibrations software.

- Tested an indoor pyranometer calibration system and associated control and data acquisition software and compared results with outdoor calibration results.

- Improved the Solar Radiation Research Laboratory web-accessible data ensemble, permitting hourly summary data to be generated from any data collection station accessible through the site.

- Responded to a total of 225 (including 135 in the first half of FY 05) technical exchanges with photovoltaic industry, academic, other national laboratories, and individuals.

- Published nine peer reviewed and conference papers describing radiometer offset correction schemes, uncertainty issues in solar radiation measurements and modeling, and optical radiometry in renewable energy research. 


\section{Acronyms}

AOP

ARM

ASTM

BB

BMS

BORCAL

BSRN

DC

DOE

EMI

EOS

FSEC

FY

GUM

HIPPS

ICS

IPC

MIDC

NASA

NIST

$\mathrm{nm}$

NOAA

NPC

NREL

OL

OMB

OTF

PASS

PMOD

PV

RADCAL annual operating plan

Atmospheric Radiation Measurement Program

American Society for Testing and Materials

blackbody

baseline measurement system

Broadband Outdoor Radiometer Calibration

baseline surface measurement network

direct current

U.S. Department of Energy

electromagnetic interference

Earth Observing System

Florida Solar Energy Center

fiscal year

guide to measurement uncertainty

high intensity pulse solar simulator

indoor calibration system

international pyrheliometer comparisons

Measurements and Instrumentation Data Center

National Aeronautics and Space Administration

National Institute of Standards and Technology

nanometer

National Oceanic and Atmospheric Administration

pyrleliometer comparison

National Renewable Energy Laboratory

optronic laboratory

Office of Management and Budget

Outdoor Test Facility

pulse analysis spectroadiometer system

Physical Meteorology Observatory, Davos

photovoltaic

Radiometric Calibration and Characterization 


$\begin{array}{ll}\text { RH } & \text { relative humidity } \\ \text { SI } & \text { international system } \\ \text { SRBB } & \text { Solar Radiation Research Branch } \\ \text { SRRL } & \text { Solar Radiation Research Laboratory } \\ \text { SULI } & \text { summer undergraduate laboratory intern } \\ \text { TSG } & \text { Transfer Standard Group } \\ \text { V } & \text { volt } \\ \text { WMO } & \text { World Meteorological Organization } \\ \text { WRR } & \text { World Radiometric Reference } \\ \text { WSG } & \text { World Standard Group }\end{array}$




\section{Contents}

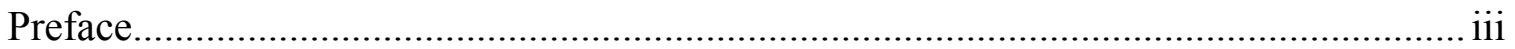

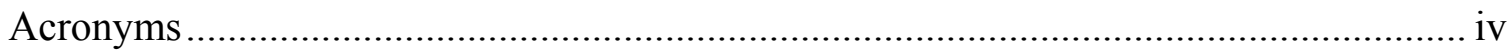

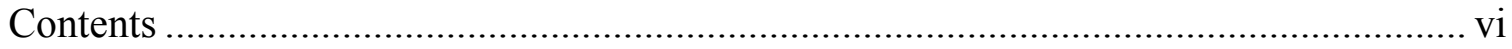

List of Figures ............................................................................................... vii

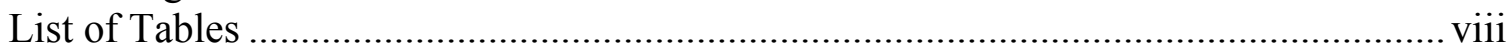

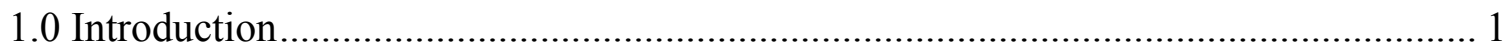

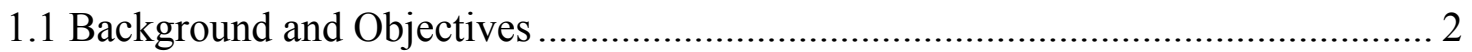

1.2 Major FY 2005 Milestones and Deliverables ………................................................ 2

2.0 Spectroradiometric Calibrations and Measurements ................................................... 3

2.1 Spectroradiometer Upgrades and Improvements .................................................. 4

2.2 Spectroradiometer Calibrations ..................................................................... 5

2.3 Spectral Calibration Uncertainty Analysis........................................................... 7

2.4 Example Spectral Measurement Results............................................................ 9

2.4.1 NREL Simulator Measurements ............................................................. 9

2.4.2 Simulator Measurements for PV Industry ................................................... 13

2.5 Updating NREL Spectroradiometer Systems ……………................................. 15

3.0 Broadband Calibrations and Research ............................................................... 16

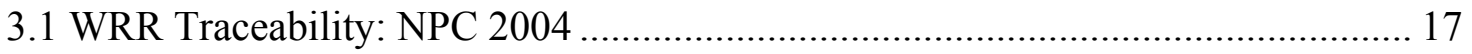

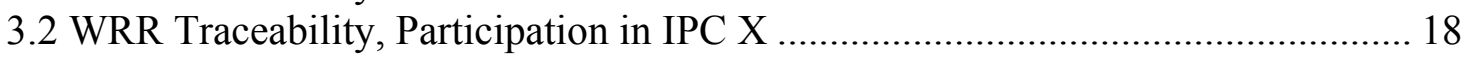

3.3 Characterizing Solar Radiometer Uncertainty and Performance ............................ 20

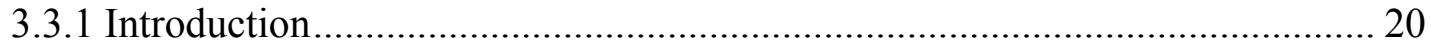

3.3.2 Thermal Offsets in Thermopile Pyranometers............................................... 20

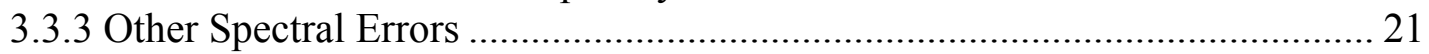

3.3.4 Longwave Responsivity of Shortwave Radiometers .................................... 22

3.3.5 Geometric, Environmental, and Equipment Uncertainty................................. 23

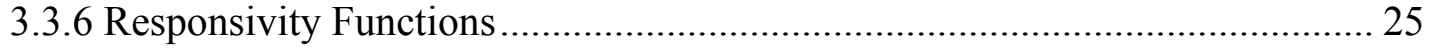

3.3.7 Pyranometer Corrections from Field Data...................................................... 26

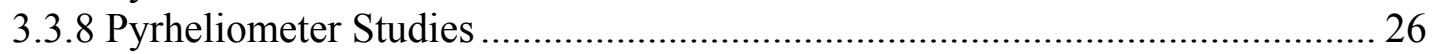

3.3.9 Revisions to ASTM Radiometer Calibration Standards …………………...... 32

3.4 Upgrade of NREL Radiometer Calibration System................................................. 34

3.5 Evaluation of Indoor Calibration System (ICS) for Pyranometers ......................... 36

4.0 Upgrades to the Measurement and Instrumentation Team Website .......................... 42

5.0 Solar Radiometric Metrology Interactions-Second Half of FY 2005 ...................... 44

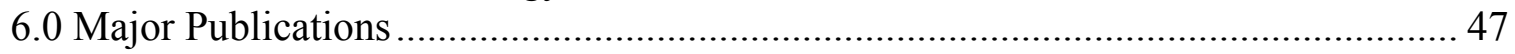

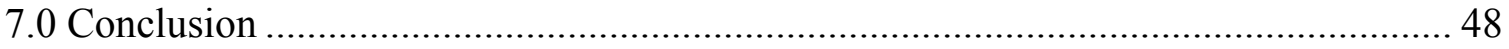

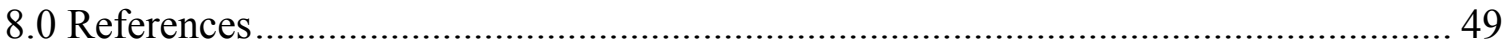




\section{List of Figures}

Figure 2.1: Improved throughput of PASS spectroradiometer input optic, ratio of signal through new spectrolon sphere to old barium sulfate sphere.

Figure 2.2. Ratio (center line) of new to previous calibration showing changes in

responsivity of the test spectrometer. Top and bottom envelopes are uncertainty limits for measured data. The difference at 1400 and $1900 \mathrm{~nm}$ region is due to the $6 \%$ difference in relative humidity between calibrations ( $24 \%$ vs $30 \%$ for previous calibration)............... 6 Figure 2.3. AIM database entry for spectroradiometer calibrations. ASCII versions of calibration files and report documents are accessed though links at the bottom of the frame.

Figure 2.4. Flash simulator pulse shapes measured in FY 05. Right to left: Spheral Solar 13 ms (long flat top), Spheral Solar $0.25 \mathrm{~ms}$, NREL Russian 1 to 42 sun, NREL HIPSS, Spire Model 460, Spire Model 350i, Spire Model 240, and Spire Model 660. For clarity, the pulse shapes have been shifted in time by $0,1.5,3,5,7.5,8.5,10.5$, and $14 \mathrm{~ms}$, respectively.

Figure 2.5 Spectral distribution measurements of NREL Spire 240A flash solar simulator from 2003 to 2005 .

Figure 2.6 NREL HIPSS normalized pulse shapes as a function of wavelength. Pulse shape variation shown to be minimal from $400 \mathrm{~nm}$ to $1400 \mathrm{~nm}$. Noise in $1400 \mathrm{~nm}$ pulse is due to decreasing signal within the pulses at longer wavelengths............................... 12 Figure 2.7. Russian pulse solar simulator pulse shapes at various wavelengths. ........... 13 Figure 2.8. Russian pulse solar simulator spectral distribution at 1 and 45 suns ............. 13 Figure 2.9 Report and ISO17025 compliant calibration certificate for FSEC Spire 660 flash solar simulator. Such reports are generated for every simulator characterization provided by the task.

Figure 2.10. "Long pulse" flash profile for Spire prototype flash simulator under development (left) and Spire 350i spectral distribution compared with ASTM G-173 standard spectrum.

Figure 3.1 Pyrheliometers for measuring direct-normal solar radiation.......................... 16

Figure 3.2 Pyranometer for measuring global-hemispherical radiation. ......................... 16 Figure 3.3 IPC meeting site, WRC/PMOD Davos, Switzerland, (left) and World Standard Group (WSG) of absolute cavity radiometers (including NREL TMI 67814) ................ 19 Figure 3.4 Solar radiation measurement instruments and the components they measure. 20 Figure 3.5. Pyranometer responsivity versus solar zenith angle. Dotted lines are $+4 \%$ and $-4 \%$ away from mean $\operatorname{Rs}\left(45^{\circ}\right)$. 25

Figure 3.6. Raw Rs varies daily and yearly due to variations in zenith angle throughout the day and year respectively (dark jagged curve). Fit of Rs function of $\cos (Z), \cos (2$ $\pi \mathrm{D} / 365)$ shown as smooth gray curve. 26

Figure 3.7 Pyrheliometer calibration data showing the variation in responsivity (ratio of signal to reference irradiance) throughout several days. Calibration factor may be computed several ways: average of all data, or average of data over selected interval or zenith angle range.

Figure 3.8. Pyrheliometers in three shaded configurations for studying environmental influences on pyrheliometer offset errors. 
Figure 3.9. Histograms of pyrheliometer zero offsets for measured (top left) shaded window pyrheliometer, and 5 models. Numbers is parenthesis are mean and standard deviation of the data sets, and the green double line is a normal distribution with the same

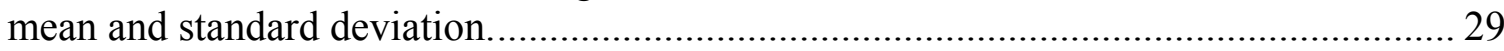

Figure 3.10 Outdoor pyrheliometer wind speed test with high speed fan. ....................... 30 Figure 3.11. Response of unshaded pyrheliometer to increased air flow of $6 \mathrm{~ms}^{-1}$ to $7 \mathrm{~ms}^{-1}$

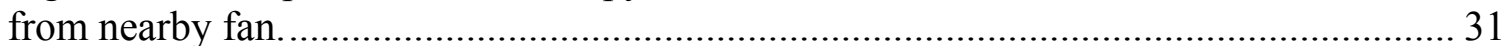

Figure 3.12. One-minute (dotted line) and hourly average ( $\mathrm{X}$ in box) difference in irradiance between two pyrheliometers, one ventilated at hourly intervals, the other

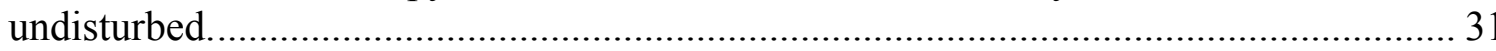

Figure 3.13 ASTM Ballot website screen image showing three standards revised under

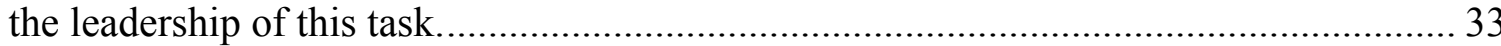

Figure 3.14 DataProof low thermal voltage scanner, which is the basis of the new RCC data collection system. Note low voltage bias of less than 1.0 microvolts..................... 34 Figure 3.15 New 100 channel custom NREL RCC high quality voltage measurement system configured for operational testing and control software development. ............... 35 Figure 3.16 Individual deviations in responsivity (in percent) between new and old data acquisition system results for NREL radiometer calibrations. Distribution of differences

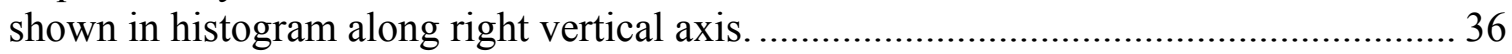
Figure 3.17. The ICS with test and reference instruments installed on the turntable....... 37 Figure 3.18. Spectral distribution of natural sunlight and ICS lamp source................... 40 Figure 4.1 Daily clear sky Langley (sunphotometer calibration) plots for narrow band channels of Atmospheric Optical Calibration System now available at Measurement and Instrumentation Data Center (MIDC) website. $500 \mathrm{~nm}$ channel shown for September 17, 2005

\section{List of Tables}

Table 1.1 Fiscal Year 2005 Annual Operating Plan Task Description.............................. 1

Table 1.2. FY 2005 Task PVC57301 Milestones and Deliverables ................................ 3

Table 2.1. NREL Spectrometer Systems ....................................................................... 4

Table 2.2. NIST specified uncertainty in standards of spectral irradiance. ...................... 6

Table 2.3. Uncertainties for $95 \%$ confidence interval, spectroradiometer calibration ....... 8

Table 2.4 Solar Spectral Measurement Requests, FY 2005 ........................................ 10

Table 3.1. Summary Results for NPC 2004 NREL Reference Cavity Radiometers....... 18

Table 3.2 History of NREL Participation in IPC Events............................................. 18

Table 3.3 Uncertainty for Pyranometer Responsivity 95\% confidence interval ............. 24

Table 3.4. Uncertainty for Pyrehliometer Responsivities 95\% confidence interval....... 27

Table 3.5. Model performance for five models estimating pyrheliometer zero offset

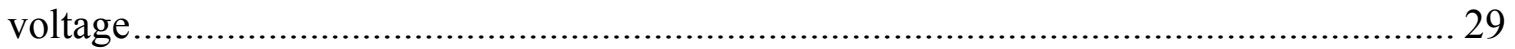

Table 3.6. Comparison of BORCAL responsivities to ICS PSP responsivities ............... 39

Table 3.7. Comparison of BORCAL and ICS Li-Cor responsivities * .......................... 39

Table 5.1 Industrial Academic, National an International Laboratory interactions ......... 44 


\subsection{Introduction}

The Solar Radiometry and Metrology Task is a component of the Photovoltaic Systems Engineering Project at the National Renewable Energy Laboratory (NREL) that provides traceable optical radiometric calibrations and measurements to photovoltaic (PV) researchers and the PV industry. The task is described in more detail in the fiscal midyear progress report [1] Table 1.1 shows the task description prepared for fiscal year 2005 Solar Program Annual operating Plan.

Table 1.1 Fiscal Year 2005 Annual Operating Plan Task Description

\begin{tabular}{|l|c|l|c|}
\hline Task Title & Organization & Task Description & $\begin{array}{l}\text { FY 2005 } \\
\text { Budget } \\
\text { (\$K) }\end{array}$ \\
\hline $\begin{array}{l}\text { Solar } \\
\text { Radiometry \& } \\
\text { Metrology }\end{array}$ & NREL & $\begin{array}{l}\text { This task provides world-class and traceable solar } \\
\text { radiometric measurements, instrumentation, and } \\
\text { metrology required by the PV Systems } \\
\text { Engineering Project and other projects. }\end{array}$ & 625 \\
\hline
\end{tabular}

The task maintains reference standards, expertise, and capability for calibration (metrology) and optical radiation measurements supporting the needs of DOE and industry research and manufacturing groups. This capability includes nine spectroradiometer systems, periodically calibrated against National Institute of Standards and Technology (NIST) sources, and used to perform measurements of natural sunlight and solar simulators in compliance with the ISO 17025 [2] accreditation of NREL Secondary Solar Reference Cell Calibrations. The spectral distributions of continuous and pulsed solar simulators are used to compute PV performance with respect to standard reporting conditions.

NREL broadband solar radiometers are calibrated to the World Radiometric Reference (WRR) through periodic (every five year) participation in World Meteorological Organization (WMO) International Pyrheliometer Comparisons (IPC) conducted at the WMO World Radiation Center at Davos, Switzerland [3] . Four NREL absolute cavity radiometers maintain the WRR at NREL, and are the reference for the calibration of about 300 broadband radiometers by the task per year. The NREL reference cavity radiometers will participate in the tenth IPC at Davos, Switzerland, in October, 2005.

Task researchers calibrate ten spectral radiometers and more than 200 broadband radiometers every year. In addition, we characterize pyranometer and pyrheliometer thermal offset errors with laboratory and spectral modeling tools, investigate environmental effects upon pyrheliometers for measuring direct normal solar radiation, and measure detailed spectral distributions of the NREL and industry solar simulators. By participating in the American Society for Testing and Materials (ASTM), in accordance 
with Office of Management and Budget (OMB) circular A-119 ${ }^{1}$, we updated three standard methods for calibrating solar radiometers reflecting present state-of-the-art knowledge. Optical metrology functions have been integrated into the NREL quality system and audited for ISO 17025 compliance.

\subsection{Background and Objectives}

The major activity and thrust of this project is the near-term and long-term performance monitoring, characterization, and modeling of emerging-technology, small $(<5 \mathrm{kWp})$, grid-connected, prototype systems installed and operating at NREL's Outdoor Test Facility (OTF). Critical to this effort is a supporting task that provides world-class and traceable measurements and instrumentation for solar radiometry. The precision and accuracy of PV system (and module) performance measurements is determined by the quality, precision, and accuracy of the measurements of the incident (on the PV arrays) solar irradiance (i.e. "power in"). We support the development of industryconsensus/adopted codes and standards that address radiometric components in testing PV devices and systems. This project is integral to the Solar Energy Technologies Program Multi-year Technical Plan, and provides credible/independent data, analyses, and assessments of the performance and reliability metrics that are required to benchmark the candidate technologies and support the systems-driven-approach to R\&D management. The next section summarizes the task deliverables described in the FY 2005 AOP for this task.

\subsection{Major FY 2005 Milestones and Deliverables}

The major expected FY 2005 accomplishments of the task include:

- Continued world-class solar radiometric, and therefore PV system performance, measurements, and instrumentation

- Reporting research progress in technical reports and journal articles.

Table 1.2 summarizes the deliverables described in the FY 2005 AOP. NREL Technical report NREL/TP-560-37594 reported on progress to March, 2005. The rest of this report describes key research and measurement accomplishments in the last six months of FY 2005 that support the above deliverables.

\footnotetext{
${ }^{1}$ see http://www.whitehouse.gov/omb/circulars/a119/a119.html
} 
Table 1.2. FY 2005 Task PVC57301 Milestones and Deliverables

\begin{tabular}{|l|c|c|c|c|}
\hline \multicolumn{1}{|c|}{ Milestone or Deliverable } & $\begin{array}{c}\text { Task } \\
\text { No. }\end{array}$ & $\begin{array}{c}\text { Due } \\
\text { Date }\end{array}$ & $\begin{array}{c}\text { Priority } \\
\text { Level }\end{array}$ & Status \\
\hline $\begin{array}{l}\text { Complete mid-year and annual summary } \\
\text { report of NIST traceable/ISO 17025 } \\
\text { compliant optical calibrations of NREL } \\
\text { and PV industry radiometers. }\end{array}$ & 2 & $\begin{array}{c}03 / 31 / 05 \\
09 / 30 / 05\end{array}$ & 4 & This Report \\
\hline $\begin{array}{l}\text { Complete proposed revised ASTM } \\
\text { pyranometer calibration standards }\end{array}$ & 2 & $03 / 31 / 05$ & 5 & Accomplished \\
$1 / 15 / 05$
\end{tabular}

\section{0 Spectroradiometric Calibrations and Measurements}

Spectral distribution of the optical radiation used while testing PV devices either in the laboratory or outdoors is needed to properly correct test data to standard reporting conditions [4], or assess observed variation in long term PV array and system performance. The Solar Radiometry and Metrology task manages a collection of spectroradiometer systems to assist NREL researchers and PV industry partners in identifying spectral issues with performance data. A subset of these instruments is used in calibrating secondary PV reference cells. Part of the ISO accreditation is the requirement for traceability of all calibrations and measurements to the International System (SI) of units. Table 2.1 lists the spectroradiometer systems, useful wavelength range, and main applications. 
Table 2.1. NREL Spectrometer Systems

\begin{tabular}{|c|c|c|}
\hline $\begin{array}{l}\text { Spectroradiometer } \\
\text { System }\end{array}$ & $\begin{array}{l}\text { Wavelength } \\
\text { Ranqe }\end{array}$ & Application \\
\hline OL-750 \#1 & $280 \mathrm{~nm}-2400 \mathrm{~nm}$ & $\mathrm{X}-25$ simulator spectral tuning and monitoring \\
\hline OL-750 \#2 & $280 \mathrm{~nm}-2400 \mathrm{~nm}$ & $\begin{array}{l}\text { Large Area continuous Solar Simulator (LACCS) } \\
\text { Integrated Pulse measurements }\end{array}$ \\
\hline OL-756 & $250 \mathrm{~nm}-800 \mathrm{~nm}$ & $\begin{array}{l}\text { New Reference UV Radiometer Calibration UV } \\
\text { source characterization; UV hazard }\end{array}$ \\
\hline OL-754 & $250 \mathrm{~nm}-800 \mathrm{~nm}$ & $\begin{array}{l}\text { Older, slower UV spectrometer for UV source } \\
\text { characterization }\end{array}$ \\
\hline LI-1800 PRS 102 & $300 \mathrm{~nm}-1100 \mathrm{~nm}$ & \multirow{4}{*}{$\begin{array}{l}\text { PV reference cell calibration outdoors; X-25, Large } \\
\text { Area Continuous; Laboratory small scale } \\
\text { simulators, special outdoor measurements. }\end{array}$} \\
\hline LI-1800 PRS 158 & $300 \mathrm{~nm}-1100 \mathrm{~nm}$ & \\
\hline LI-1800 PRS 174 & $300 \mathrm{~nm}-1100 \mathrm{~nm}$ & \\
\hline Li-1800 PRS 218 & $300 \mathrm{~nm}-1100 \mathrm{~nm}$ & \\
\hline ASD FieldSpec & $350 \mathrm{~nm}-2100 \mathrm{~nm}$ & $\begin{array}{l}\text { Natural and Artificial Source Characterization; } \\
\text { integrated Pulse simulator measurement }\end{array}$ \\
\hline $\begin{array}{l}\text { Pulse Analysis } \\
\text { Spectroradiometer } \\
\text { System }\end{array}$ & $250 \mathrm{~nm}-1800 \mathrm{~nm}$ & $\begin{array}{l}\text { Detailed Characterization Pulse lamp sources; } \\
\text { Spire 240, High Intensity Pulse Solar Simulator } \\
\text { (HIPSS) }\end{array}$ \\
\hline
\end{tabular}

In each instance, a measure of the quantity and quality of optical radiation seen by the PV devices is important in establishing technology performance. For laboratory sources, it is important that the quality of the illumination, as measured by the spectral distribution of the source, is comparable to sunlight, or characterized for the departure from the spectral distribution of sunlight.

\subsection{Spectroradiometer Upgrades and Improvements}

In the second half of FY 2005, the task purchased the new OL-756 Reference UV Spectroradiometer system to improve our productivity and capability with respect to UV source characterization and calibration of UV band sensors. The new capability includes rapid scanning capability (up to 256 spectra a minute) and direct import of data into spreadsheet applications for analysis.

We improved the stability of the infrared (lead sulfide) detector in the OL-750 systems. These detectors rely on an accurate, stable $-60 \mathrm{~V}$ DC bias voltage, usually provided by two 30 Volt alkaline dry cell batteries. Degradation in battery performance over periods between calibrations can lead to incorrect and unstable spectral data beyond $1100 \mathrm{~nm}$. We selected an electronic power supply to eliminate the need for the batteries in the $\mathrm{PbS}$ detector assembly.

We also upgraded the Pulse Analysis Spectroradiometer System (PASS) MKII with a new integrating sphere input optic that is much more stable and has an improved throughput, as shown in Figure 1. 


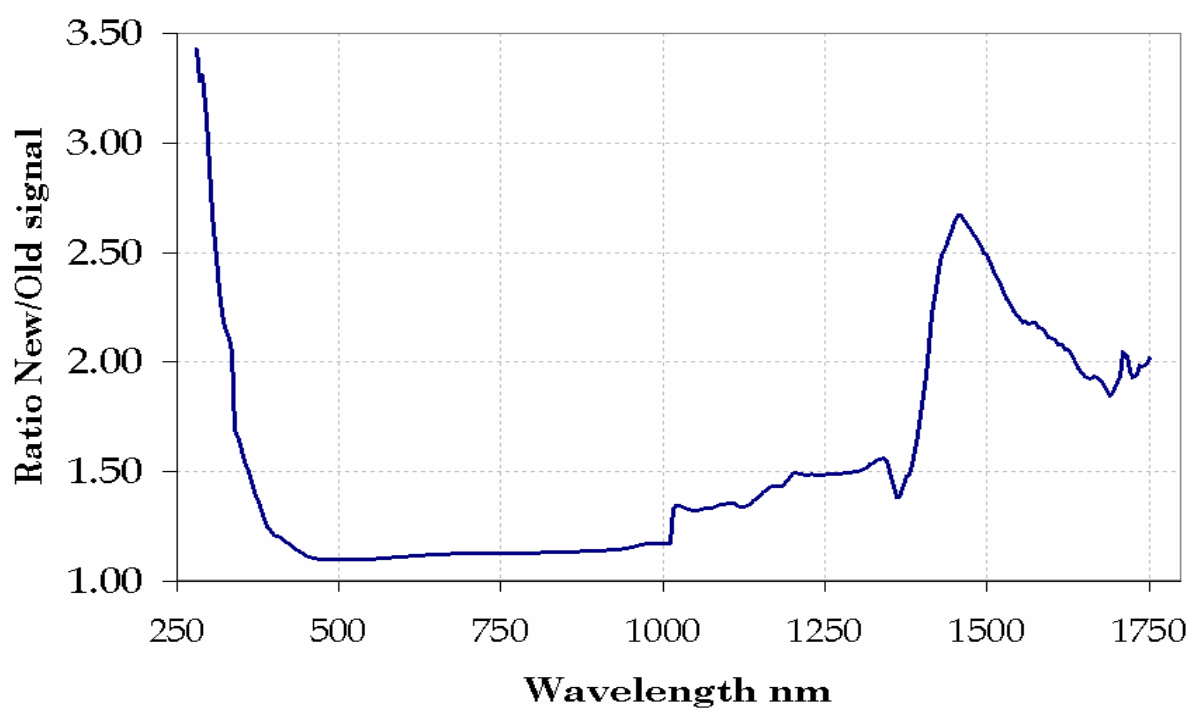

Figure 2.1: Improved throughput of PASS spectroradiometer input optic, ratio of signal through new spectrolon sphere to old barium sulfate sphere.

\subsection{Spectroradiometer Calibrations}

Spectroradiometers used at NREL include classic scanning grating monochromators and diode array spectroradiometers. Calibration of these spectroradiometers is performed with respect to standards of spectral irradiance purchased directly from the NIST Optical Technology Division ${ }^{\dagger}$. NIST provides a calibrated $1000 \mathrm{~W}$ incandescent tungsten halogen lamp with tabulated spectral irradiance data at about 30 wavelengths [5]. The lamp is calibrated at a certain direct current (DC), usually 8.2 amperes, and a specified distance $(500 \mathrm{~mm})$ from the front surface of the lamp bi-post pins. The user must reproduce the current specified by NIST, with stability better than $0.01 \%$. The calibration geometry, especially the calibration distance, must also be reproduced as accurately as possible. This requires stable DC power supplies and precision calibration geometry setup fixtures. NIST supplies a statement of uncertainty with the spectral calibration, as shown in Table 2.2. A typical spectral calibration consists of recording the response of the spectroradiometer system, including input optics, monochromator, and detectors, when viewing the calibration source (spectral standard lamp) at each wavelength. Section 2.1 in the midyear progress report [1] discusses general principles.

\footnotetext{
${ }^{\dagger}$ see http://physics.nist.gov/Divisions/Div844/facilities/fascal/fascal.html
} 
Table 2.2. NIST Specified Uncertainty in Standards of Spectral Irradiance.

\begin{tabular}{|c|c|c|}
\hline Wavelength (nm) & Typical Values $\mathbf{( W / \mathbf { c m } ^ { - 3 } )}$ & $\begin{array}{c}\text { Relative Expanded } \\
\text { Uncertainty, } \boldsymbol{k = 2} \mathbf{( \% )}\end{array}$ \\
\hline 250 & 0.2 & 1.8 \\
\hline 350 & 7.0 & 1.1 \\
\hline 655 & 170 & 0.9 \\
\hline 900 & 215 & 1.1 \\
\hline 1600 & 115 & 1.4 \\
\hline 2400 & 40 & 4.4 \\
\hline
\end{tabular}

Additional sources of uncertainty in the local laboratory calibrations, and in various measurement scenarios must be accounted for, as described in the next section.

During the first (October) and second (March) quarter of FY 05, we calibrated nine of the ten spectroradiometer systems listed in Table 2.1. Calibration results, reports, and data are recorded in an electronic data base (Atmospheric Radiation Measurement [ARM] program Instrument Management system, or AIM) accessible at http://www.nrel.gov/aim/database.html.

Each calibration consists of a wavelength check by measuring emission sources of known wavelength. After taking corrective action regarding wavelength test results that are out of tolerance, the spectroradiometer responsivity is generated using a NIST lamp. The same lamp is then measured as an unknown, to assure the calibration response was properly generated. Finally, the new calibration is compared with the last calibration to provide information on radiometer drift with time. Figure 2.2 shows the ratio of a new to old calibration.

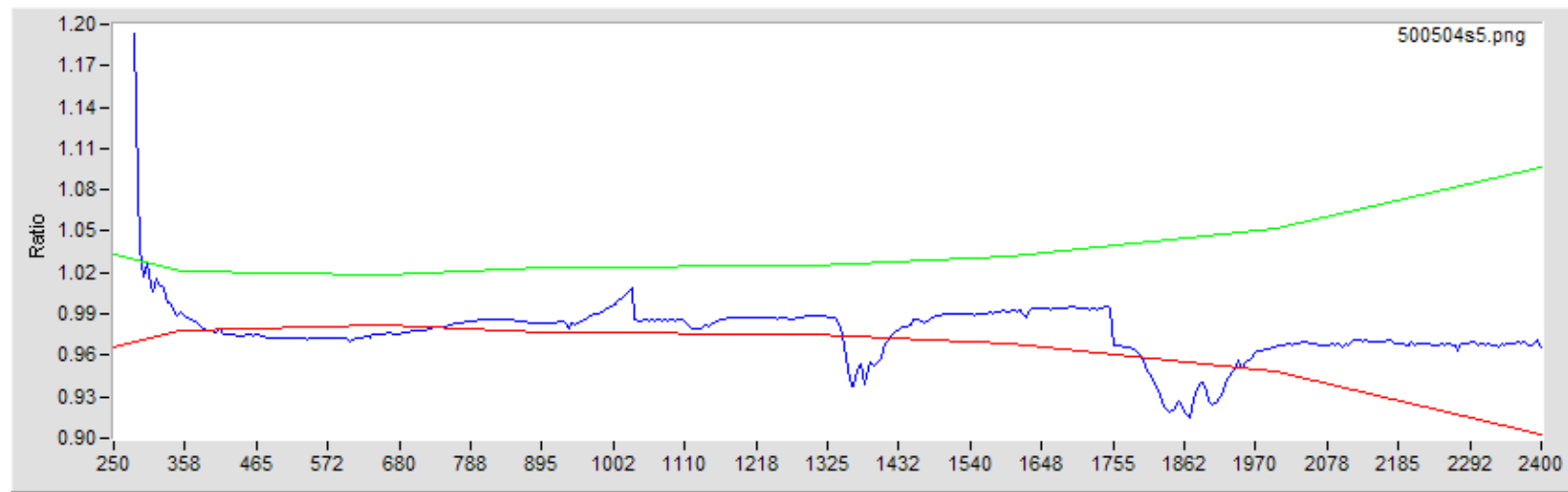

Figure 2.2. Ratio (center line) of new to previous calibration showing changes in responsivity of the test spectrometer. Top and bottom envelopes are uncertainty limits for measured data. The difference at 1400 and $1900 \mathrm{~nm}$ region is due to the $6 \%$ difference in relative humidity between calibrations ( $24 \%$ vs $30 \%$ for previous calibration).

The final new calibration file and a calibration report are entered into the AIM database. The report is used to elucidate any special problems or issues with the spectroradiometer system. Figure 2.3 is an example AIM database record for one of the spectroradiometers used to monitor the Spectrolab X-25 solar simulator - the Large Area Continuous Solar Simulator, or outdoor data during PV reference cell calibrations. 


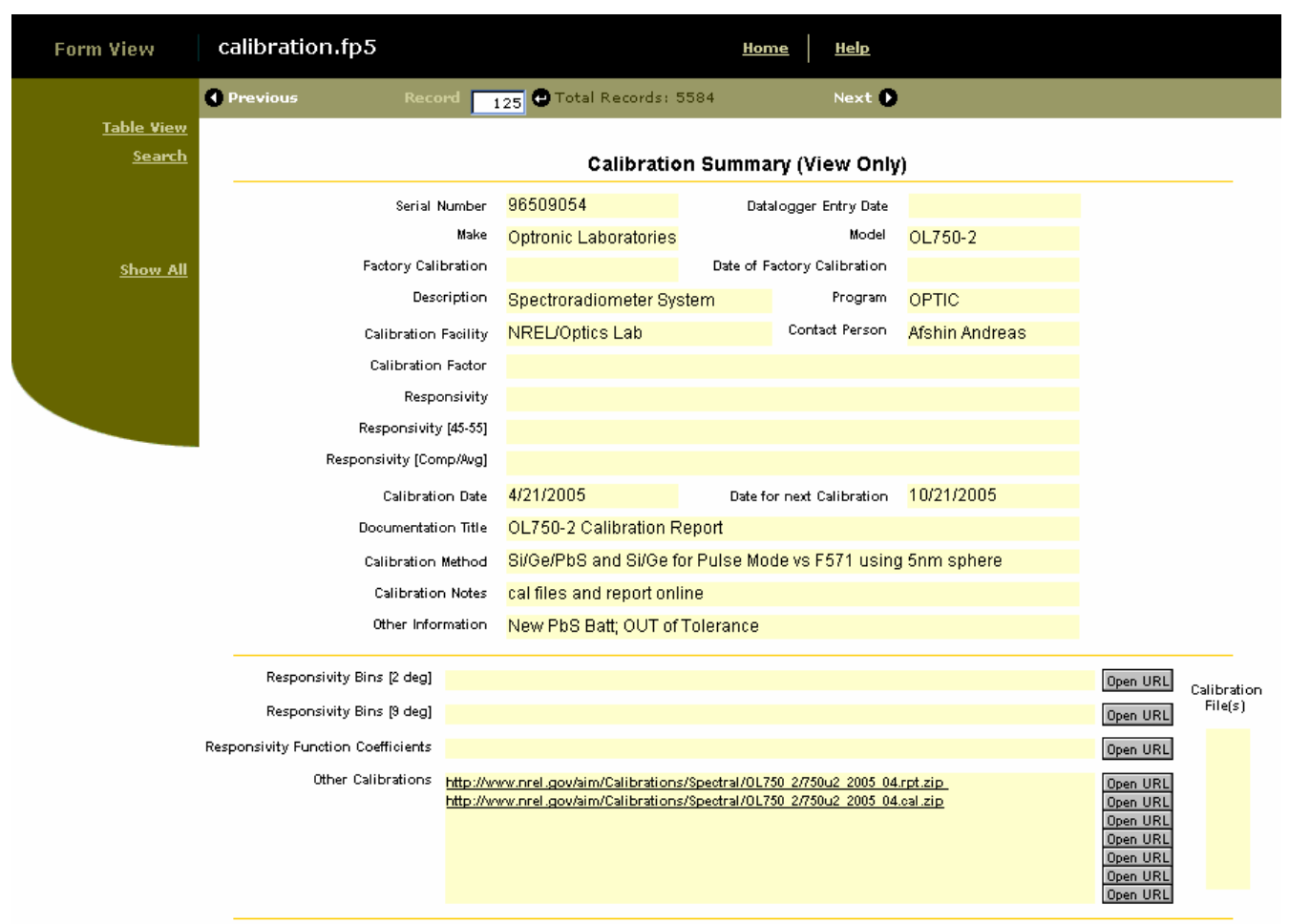

Figure 2.3. AIM database entry for spectroradiometer calibrations. ASCII versions of calibration files and report documents are accessed though links at the bottom of the frame.

All NREL spectrometers are calibrated at nearly the same time (within 1 week of each other) to prevent the possibility of differing times between calibrations becoming an issue when the same source is measured by several spectrometers with disparate results.

Besides posting calibration results in the AIM database, new calibration files and reports are posted on a secure internal NREL server for use by the PV Measurements Group for easy access to historical data and reports, in case questions arise during new measurement activities. Calibration intervals have been set at six-month intervals because changes such those shown in Figure 2.2 can be seen over this interval. Longer intervals between calibrations can result in greater drift and the need for larger corrections. In addition, we performed research that shows that calibration files are sensitive to atmospheric water vapor (relative humidity, RH) in the laboratory (as indicated in the caption to Figure 2.2), so we schedule calibrations at times (spring, fall) when the relative humidity in the NREL Optical Metrology Laboratory is consistent with the expected RH in measurement laboratories at NREL.

\subsection{Spectral Calibration Uncertainty Analysis}

Each measurement only approximates the quantity being measured, and is incomplete without a quantitative uncertainty. Every element of a measurement system contributes elements of uncertainty. Historically, uncertainty analysis treated sources of uncertainty in terms of "random" and "bias" types. Random sources of uncertainty were related to the 
standard deviation or variance of measured data sets. Biases were estimates of deviations from a "true value." Total uncertainty, $\mathrm{U}$, was computed from: $\mathrm{U}^{2}=\Sigma(\text { Bias })^{2}+$

$\Sigma(2 * \text { Random })^{2}$. The factor of 2 in the random term was necessary to "inflate" the random component to provide approximately a $95 \%$ confidence interval for the computed $U$.

The Guide to Measurement Uncertainty (GUM) of the International Bureau of Weights and Measures is presently the accepted guide for measurement uncertainty $[6,7]$. The GUM defines Type A uncertainty values as derived from statistical methods, and Type B sources as evaluated by "other means", such as scientific judgment, experience, specifications, comparisons, or calibration data. The GUM defines the concept of a "standard uncertainty" for each uncertainty type, which is an estimate of an "equivalent" standard deviation (of a specified distribution). The GUM replaces the historical factor of two with a "coverage factor", $k$ (dependent upon the known or assumed statistical distribution of uncertainties), and $\mathrm{U}^{2}=\Sigma$ (Type B $)^{2}+\Sigma\left(k^{*} \text { Type A }\right)^{2}$. For small $(\mathrm{n}<20)$ samples from a normal distribution, $k$ may be selected from the student's t-distribution [8] U is the "Expanded Uncertainty", and $k$ is usually in the range of 2 to 3, for confidence intervals of $95 \%$ and $99 \%$, respectively. When a result, $\mathrm{R}$, is functionally dependent upon several $i=1, \ldots, n$ variables, $x_{i}$, the familiar propagation of error formula $U^{2}=\sum_{i i}\left(\partial_{X_{i}} R \cdot e_{X i}\right)^{2}$ is used. $\mathrm{U}$ is the uncertainty in the resultant, $\mathrm{e}_{\mathrm{xi}}$, and is the estimated uncertainty in variable $\mathrm{x}_{\mathrm{i}}$, and $\partial_{\mathrm{xi}} \mathrm{R}$ is the partial derivative of the response $\mathrm{R}$ with respect to variable $\mathrm{x}_{\mathrm{i}}$, called the sensitivity function for variable $\mathrm{x}_{\mathrm{i}}$.

As detailed in the midyear progress report [1] , in the first quarter of FY 05, we revisited our calibration and measurement uncertainty analysis for the Optronic Laboratory OL750 and OL-754 spectrometer systems, which are critical reference spectrometers, as shown in Table 2.3

\section{Table 2.3. Uncertainties for $95 \%$ Confidence Interval, Spectroradiometer Calibration}

\begin{tabular}{lcc} 
TYPE A (Statistical) UNC (\%) & STD UNC (\%) \\
\hline Distance $(2 / 500 \mathrm{~mm})$ & 0.80 & 0.400 \\
Wavelength Precision & 0.01 & 0.005 \\
Power current (Irr dI/di \%) 0.20 & 0.200 \\
NIST Lamp Precision & 1.13 & 0.565 \\
Detector Sig/Noise & $1.0 \mathrm{e}-4$ & $5.0 \mathrm{e}-5$ \\
Sig Detection Sys & 1.00 & 0.500 \\
Temp sensitivity & 1.00 & 0.500 \\
Observed Noise (\% reading) & 3.00 & 1.500
\end{tabular}

\begin{tabular}{lcc} 
TOTAL & UNCERT $(\%)$ & STD UNCERT (\%) \\
\hline Type A & 3.600 & 1.808 \\
Type B & 2.001 & 1.015 \\
COMBINED & $\mathbf{4 . 1 5 4}$ & $\mathbf{2 . 0 7 7}$ \\
\hline
\end{tabular}

\begin{tabular}{llc} 
TYPE B & UNC (\%) & STD UNC (\%) \\
\hline NIST Transfer & 1.82 & 0.910 \\
Distance & 0.8 & 0.400 \\
Stray Light & $1 \mathrm{e}-4$ & 0.00005 \\
Lamp Alignment & 0.10 & 0.050 \\
Power Current & $* 0.20$ & 0.200 \\
Shunt Bias & 0.04 & 0.020 \\
Wavelength & 0.01 & 0.005
\end{tabular}

\begin{tabular}{lc} 
EFFECTIVE DEG. OF FREEDOM & $>100$ \\
COVERAGE FACTOR (k) & 2 \\
CONFIDENCE INTERVAL & $95 \%$ \\
EXPANDED UNCERTAINTY & $\mathbf{4 . 1 4 7 \%}$ \\
\hline
\end{tabular}

The test of the quality of an uncertainty analysis is that no measured values fall outside the expected range of uncertainty. Repeated measurements of several spectral irradiance standard lamps using a spectroradiometer system calibrated using a single lamp, show the 
actual range of measurement results are within the bounds computed in Table 2.3, as discussed in section 2.2 of the midyear progress report.

Measurements conducted under different conditions, and of significantly different spectral distributions, will have differences in the uncertainty envelope related to differences between the calibration spectral distribution and the distribution being measured (the effect of slit scattering function), stability of the spectroradiometer system, differing environmental conditions, etc. which need to be evaluated and combined with the calibration uncertainty on a case by case basis.

\subsection{Example Spectral Measurement Results}

Using the systems described above, we accomplished several measurements of note in the first half of FY 2005. These accomplishments were detailed in the midyear progress report (section 2.4). Table 2.4 is a comprehensive list of spectral measurements accomplished during FY 05. Figure 2.4 is a plot of the various flash simulator pulse shapes measured this fiscal year. Reading right to left, these are the Canadian custom 13 ms pulse simulator (long flat top), a Canadian $1 / 4 \mathrm{~ms}$ wide custom simulator, a Russian 5 ms wide variable intensity flash simulator, the NREL High Intensity Pulse Solar Simulator (HIPSS), Shell Solar Spire model 460, Spire Model 350i, NREL Spire 240A, and Florida Solar Energy Center (FSEC) Spire Model 660. For clarity, the pulse shapes have been shifted in time by $0,1.5,3,5,7.5,8.5,10.5$, and $14 \mathrm{~ms}$, respectively.

\subsubsection{NREL Simulator Measurements}

Repeated measurements of the NREL SPIRE 240A flash solar simulator since 2003 are shown in Figure 2.5. Long term stability of individual lamps and consistency in the flash simulator spectrum when new lamps are installed are verified with these measurements. 
Table 2.4 Solar Spectral Measurement Requests, FY 2005

\begin{tabular}{|c|c|c|}
\hline Requestor/Date & Simulator & Measurement Objective \\
\hline $\begin{array}{l}\text { Florida Solar Energy } \\
\text { Center (FSEC) Coca, } \\
\text { FL. Oct } 2004\end{array}$ & Spire 660 & ASTM E-927 Classification \\
\hline FSEC Oct 2004 & $\begin{array}{l}\text { VORTEK } 10 \mathrm{~kW} \\
\text { Continuous }\end{array}$ & $\begin{array}{l}\text { Spectral Distribution and ASTM E-927 } \\
\text { Classification }\end{array}$ \\
\hline NREL OTF Jan 2005 & $\begin{array}{l}\text { Russian loffe Physics } \\
\text { Institute Pulse Solar } \\
\text { Simulator }\end{array}$ & $\begin{array}{l}\text { Pulse shape, spectral } \\
\text { content, ASTM E-927 } \\
\text { Classification ( } 1 \text { to } 42 \text { suns) }\end{array}$ \\
\hline NREL OTF Feb 2005 & $\begin{array}{l}\text { Large Area Continuous } \\
\text { (LACSS) }\end{array}$ & $\begin{array}{l}\text { ASTM E-927 Classification before } \\
\text { relamping }\end{array}$ \\
\hline $\begin{array}{l}\text { Shell Solar, Camarillo } \\
\text { CA }\end{array}$ & $\begin{array}{l}\text { Two Spire 240, Spire } \\
\text { 460, Large Area Pulse } \\
\text { Solar } \\
\text { Simulator (LAPSS) }\end{array}$ & $\begin{array}{l}\text { Comparative spectral distribution } \\
\text { differences and ASTM E-927 } \\
\text { Classification. Resolve mismatched PV } \\
\text { module differences in performance }\end{array}$ \\
\hline NREL OTF May 2005 & LACSS & $\begin{array}{l}\text { ASTM E-927 Classification after re- } \\
\text { lamping }\end{array}$ \\
\hline NREL OTF Jun 2005 & Atlas 260 Chamber & UV Irradiance monitor calibration \\
\hline NREL OTF Jun 2005 & Atlas 1600 Chamber & UV Irradiance monitor calibration \\
\hline NREL OTF Aug 2005 & SPIRE 240A & $\begin{array}{l}\text { ASTM E-927 Classification (Pulse) } \\
\text { Establish consistency (new lamp) }\end{array}$ \\
\hline NREL OTF Sep 2005 & $\begin{array}{l}\text { High Intensity Pulse } \\
\text { Solar Simulator (HIPSS) }\end{array}$ & $\begin{array}{l}\text { Characterize spectral distribution changes } \\
\text { with respect to lamp flash voltage and } \\
\text { inter-flash interval procedures (on going) }\end{array}$ \\
\hline $\begin{array}{l}\text { SPIRE Corp., Bedford } \\
\text { MA Sep } 2005\end{array}$ & $\begin{array}{l}\text { Two Production SPIRE } \\
\text { 350i flash simulators }\end{array}$ & $\begin{array}{l}\text { ASTM E-927 Classification; provide } \\
\text { comparative data for Spire prototype } \\
\text { spectrometer measurements. }\end{array}$ \\
\hline
\end{tabular}




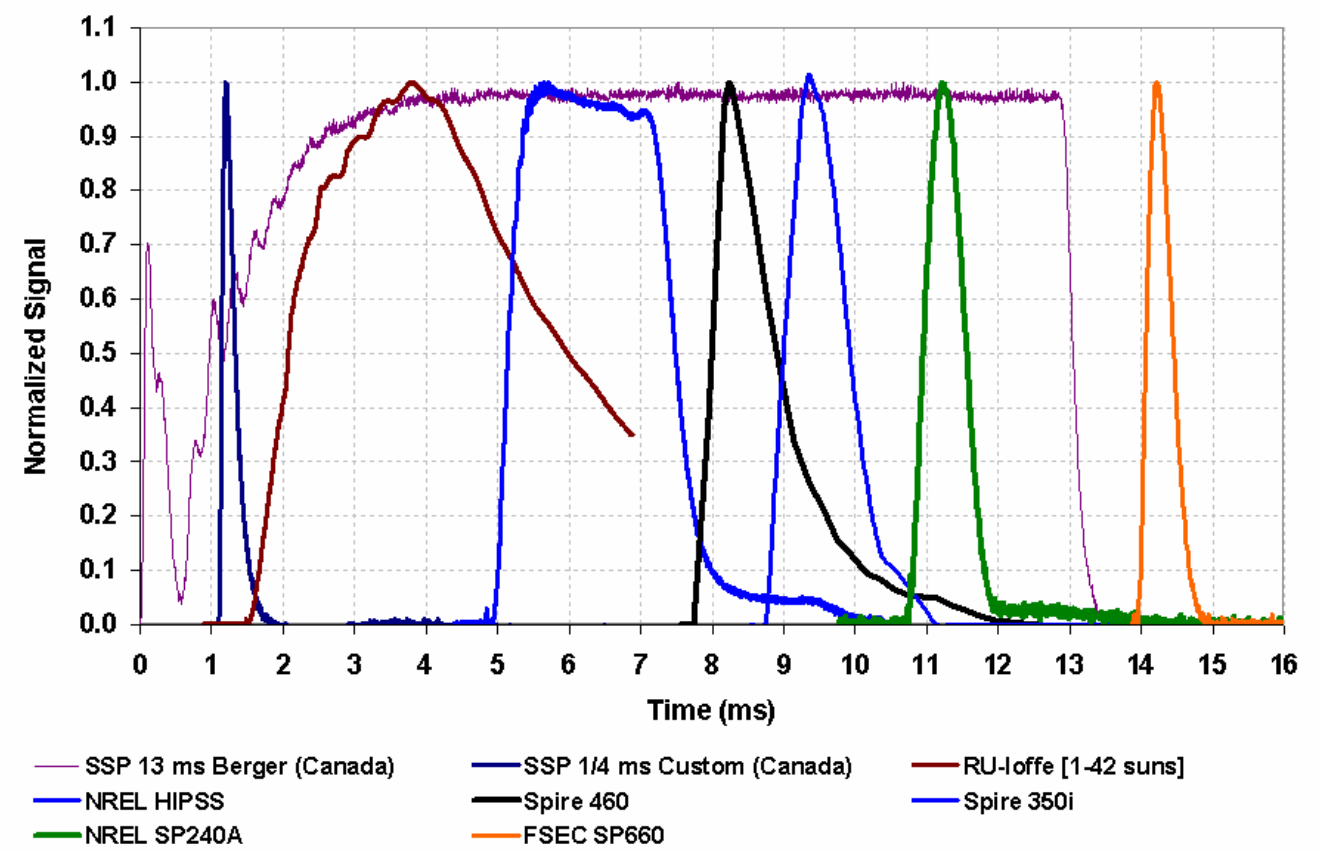

Figure 2.4. Flash simulator pulse shapes measured in FY 05. Right to left: Spheral Solar 13 ms (long flat top), Spheral Solar 0.25 ms, NREL Russian 1 to 42 sun, NREL HIPSS, Spire Model 460, Spire Model 350i, Spire Model 240, and Spire Model 660. For clarity, the pulse shapes have been shifted in time by $0,1.5,3,5,7.5,8.5,10.5$, and $14 \mathrm{~ms}$, respectively.

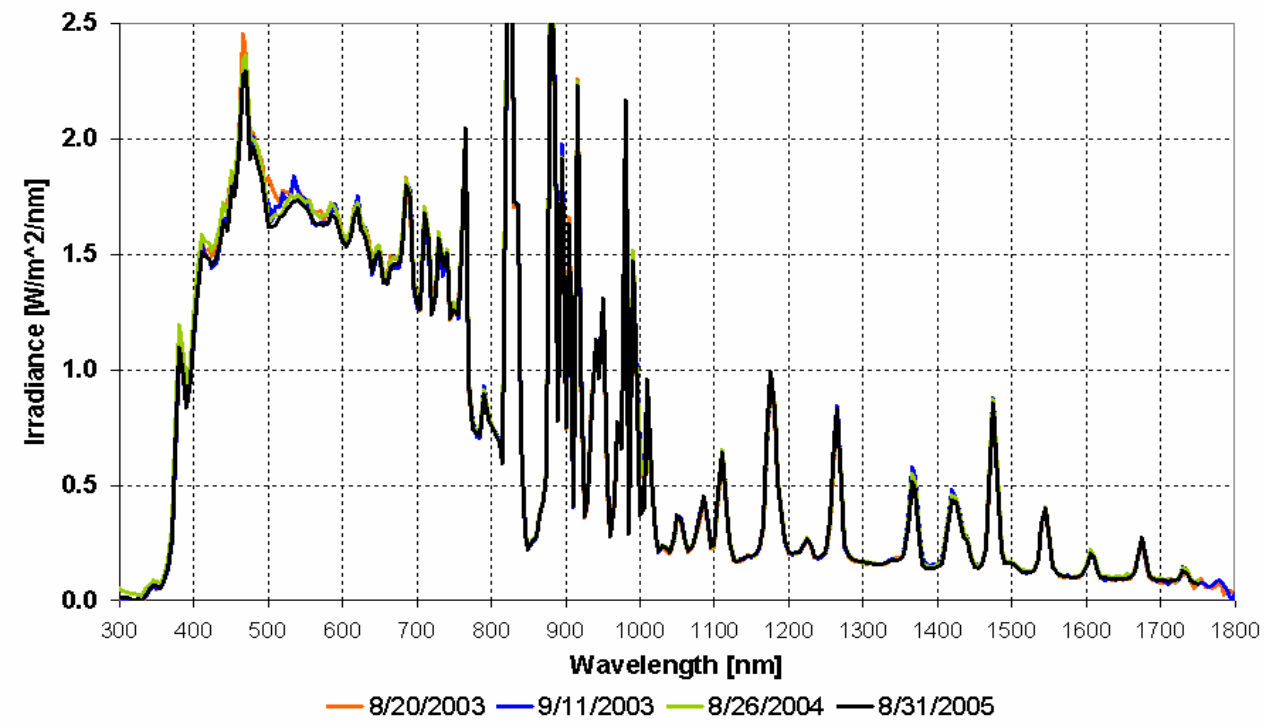

Figure 2.5 Spectral distribution measurements of NREL Spire 240A flash solar simulator from 2003 to 2005. 
NREL uses the HIPSS to study performance of solar cells under simulated concentrated sunlight, with intensity between 100 and 1000 suns. Artifacts observed in the testing of multi-junction cells indicated the need to study variation in the pulse shape of the HIPSS with wavelength. The task measured the flash profile at each of 36 wavelengths from 300 $\mathrm{nm}$ to $1800 \mathrm{~nm}$. The data (shown in Figure 2.6 for a selected subset of wavelengths) indicates that the pulse profile in time varies only slightly with wavelength.

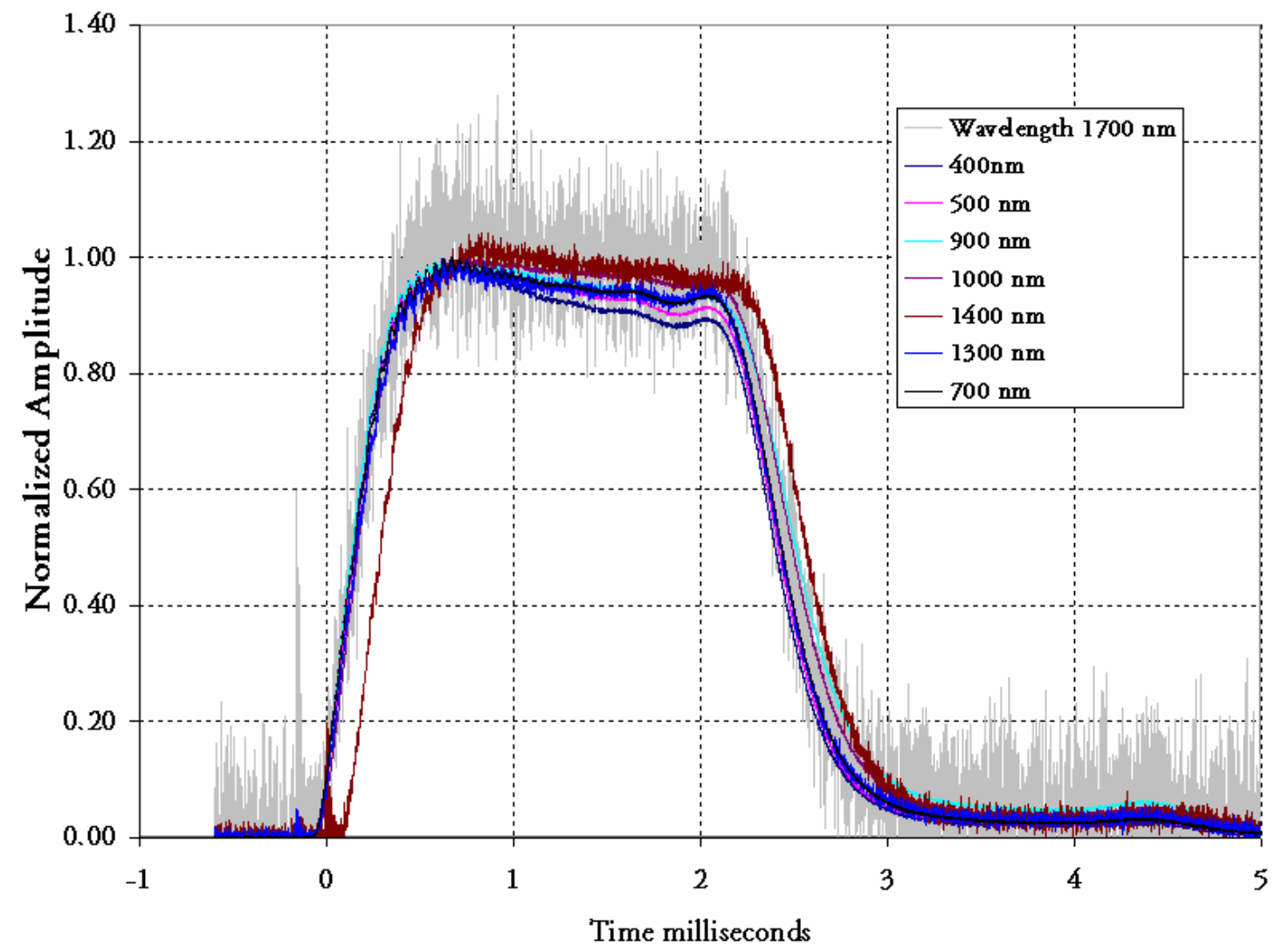

Figure 2.6 NREL HIPSS normalized pulse shapes as a function of wavelength. Pulse shape variation shown to be minimal from $400 \mathrm{~nm}$ to $1400 \mathrm{~nm}$. Noise in $1400 \mathrm{~nm}$ pulse is due to decreasing signal within the pulses at longer wavelengths.

The NREL PV Measurements and Characterization task worked with the Russian Ioffe Physico-Technical Institute to develop and test a pulse solar simulator that produces simulated solar flashes with an intensity between one and 45 suns $\left(1.0 \mathrm{kWm}^{-2}\right.$ to 45 $\mathrm{kWm}^{-2}$ ). This simulator provides an intermediate range of intensities, between the typical one-sun simulators such as the LACSS and the Spire 240A, and the HIPPS which produces flashes with intensities between 100 and 500 suns. The simulator is designed to evaluate photovoltaic devices for low to intermediate concentration ratio applications. Figure 2.7 shows the pulse shape variability of the simulator at one sun level. Figure 2.8 compares the relative spectral distributions for the simulator at either intensity extreme (1 and 45 suns). 


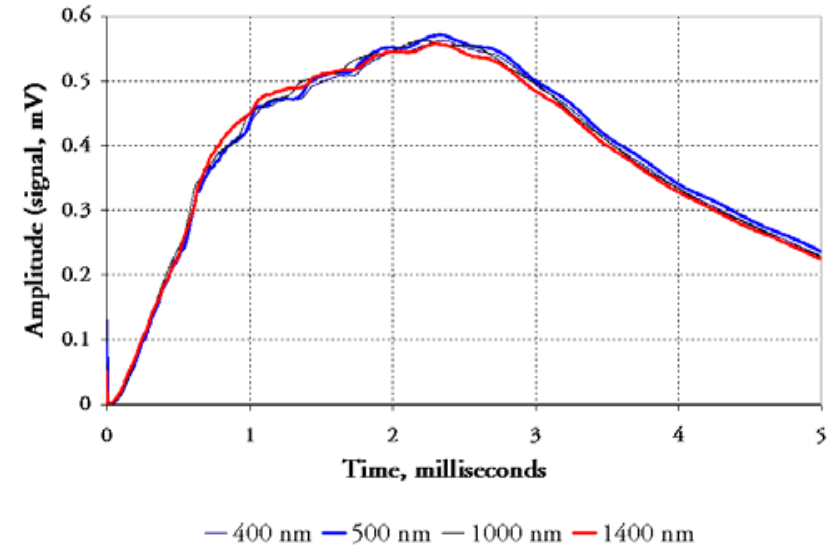

Figure 2.7. Russian pulse solar simulator pulse shapes at various wavelengths.

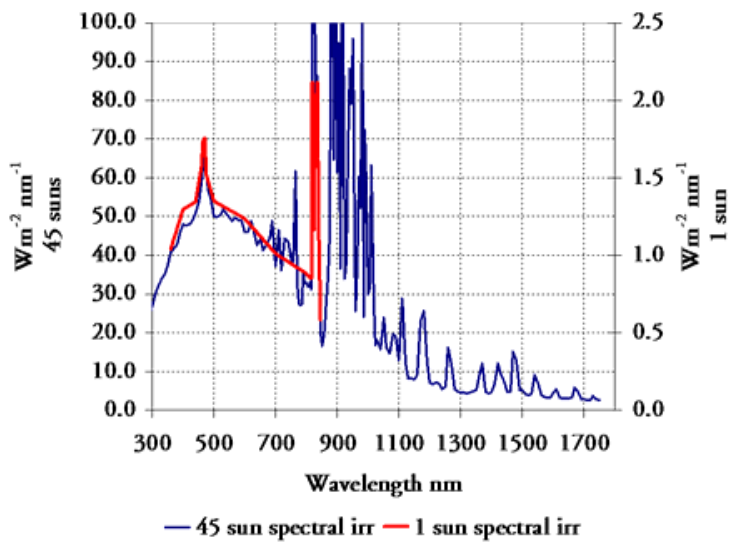

Figure 2.8. Russian pulse solar simulator spectral distribution at 1 and 45 suns

During the first half of the fiscal year, measurements of the NREL Large Area Continuous Solar simulator showed that the simulator degraded from Class A to Class B according to American Society for Testing and Materials, or ASTM, Standard E-927 on the Classification of Solar Simulators[9] . The progress of the change is documented in the series of measurement shown in the midyear report Figures 2.10 and 2.11.

All simulator measurements are archived and made available to the PV Measurements and Characterization task on a secure, locally available server, permitting that task to perform their own independent analysis using the spectral data as needed.

\subsubsection{Simulator Measurements for PV Industry.}

As mentioned in Table 2.4, we visited and measured solar simulator spectral distributions for the FSEC, Cocoa FL., Shell Solar, Camarillo, CA., and Spire Corporation, Bedford, MA.

Shell Solar was getting different performance results from the same module when tested on three different simulators in their Camarillo CA plant. They suspected that a difference in the spectral power distributions of the three simulators was the source of the different results. Therefore they requested we measure the three spectral power distributions to verify the hypothesis, and compute the proper spectral mismatch correction factor to reconcile the results. The results of these measurements were detailed in section 2.4 of the midyear progress report, Figures 2.12 to 2.15.

The FSEC at Coca, Florida is accredited to certify photovoltaic panel performance for the state of Florida. ${ }^{2}$ The accreditation is with respect to ISO 17025 standard for quality systems, requiring documentation of measurement traceability, procedures, uncertainty analysis, and a quality system. NREL supports FSEC accreditation and their quality

\footnotetext{
${ }^{2}$ see http://www.fsec.ucf.edu/pvt/BuyInstallPV/rep.html
} 
system by periodically characterizing the performance of the Spire model 660 flash simulator used in the state certification process. This requires the classification of the simulator with respect to ASTM E-927 standard method for the classification of solar simulators. The classification method requires comparing spectral distributions of the simulator with the standard spectrum. The NREL PASS system is the only system presently available to provide the ISO standard compliant measurements needed for FSEC to maintain their accredited status. We measured the FSEC model 660 simulator in March, 2005, and produced a report and ISO 17025 compliant calibration certificate to FSEC as shown in Figure 2.9.

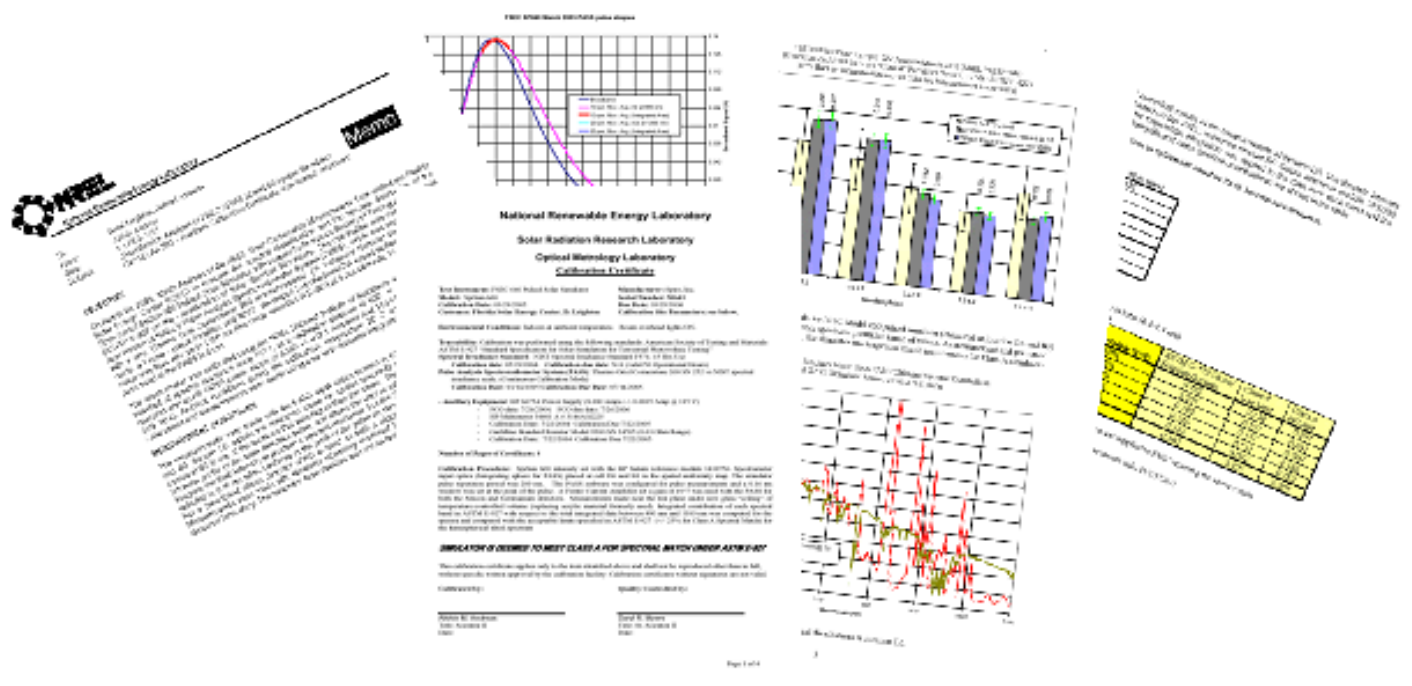

Figure 2.9 Report and ISO17025 compliant calibration certificate for FSEC Spire 660 flash solar simulator. Such reports are generated for every simulator characterization provided by the task.

The Spire Corporation of Bedford MA is a major supplier of PV production and test equipment, including flash solar simulators. Over the past several years, Spire has been developing a spectral distribution measurement capability to verify the performance of their simulator products. NREL has assisted Spire by calibrating measurement systems for them, and providing NREL measured data for comparison with the Spire measurement system. In September, 2005, Spire requested NREL measure two different serial number units of SPIRE model 350i with the NREL pass system at the Spire factory, and a measurement of the spectral distribution and pulse shape for a prototype long-pulse $(100 \mathrm{~ms})$ simulator. Figure 2.10 shows the pulse shape measured for the "long pulse" prototype. 

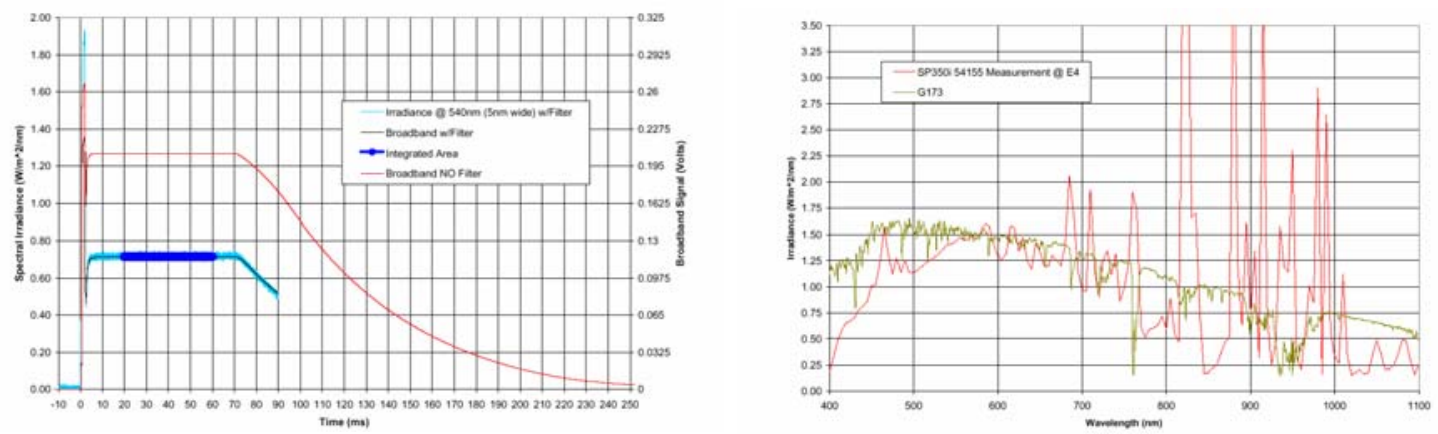

Figure 2.10. "Long pulse" flash profile for Spire prototype flash simulator under development (left) and Spire 350i spectral distribution compared with ASTM G-173 standard spectrum.

For all of measurement cases above, it is important to note that while the classification of the simulator conveys a certain amount of information, knowledge of the actual measured spectral distribution can be used to mathematically translate the result of measurements under each source to standard reporting conditions. It is this critical spectral data information, above and beyond the classification, that permits the transformation to Standard Reporting Conditions to be accomplished.

\subsection{Updating NREL Spectroradiometer Systems}

As described in the midyear progress report, the Li-Cor, Inc., LI-1800 spectroradiometer systems have been the workhorse spectral measurement systems at NREL for over 20 years. Recently, Li-Cor announced that they would no longer manufacture the systems, as certain electronic components were no longer available. Li-Cor also felt it was not costeffective for their small company to invest in upgrading or re-designing this instrument, so Li-Cor removed it from their product line. As this instrument is tightly integrated into the PV Measurement Group process for calibration of primary and secondary PV reference cells, it is critical that a suitable replacement for the Li-1800 systems be found before a major failure in one or any of the systems. Several diode array spectrometer systems were evaluated and found to be unsatisfactory substitutes for the Li-1800.

Further research located a system with flexibility, similar bandpass options, and better optical performance than the Li-1800 system. Extensive review of specifications and discussions with various suppliers of spectroradiometer systems lead to the selection of a classical scanning grating system candidate replacement from Instruments Systems, Inc. Model SP320 model $114^{3}$. A request for quote, and a purchase request for this unit as a capital equipment item were prepared, and the order for the unit placed in August, 2005. In the coming fiscal year, the task will calibrate the unit and integrate it into the periodic calibration cycle for all NREL solar program spectrometers, under the ISO17025 compliant quality system in place for the PV Reference Cell and PV Reference Module scope of the NREL accreditation for these activities.

\footnotetext{
${ }^{3}$ http://www.instrumentsystems.com/Products/spectro320.pdf
} 


\subsection{Broadband Calibrations and Research}

Evaluating photovoltaic (PV) cells, modules, arrays, and systems performance relies on accurately measuring the available solar radiation resources for conversion.

Pyrheliometers (Figure 3.1) measure the shortwave ( 0.3 micrometer to 2.5 micrometer wavelength) solar radiation direct-beam radiation within a $5^{\circ}$ field of view around the solar disk. Pyranometers (Figure 3.2) measure the total shortwave solar radiation, also called global or hemispherical solar radiation, in a hemispherical ( $2 \pi$ steradian) field of view. Pyranometer measurements are used to characterize performance of flat-plate PV technologies, and pyrheliometer measurements are important for concentrating solar collector technologies.

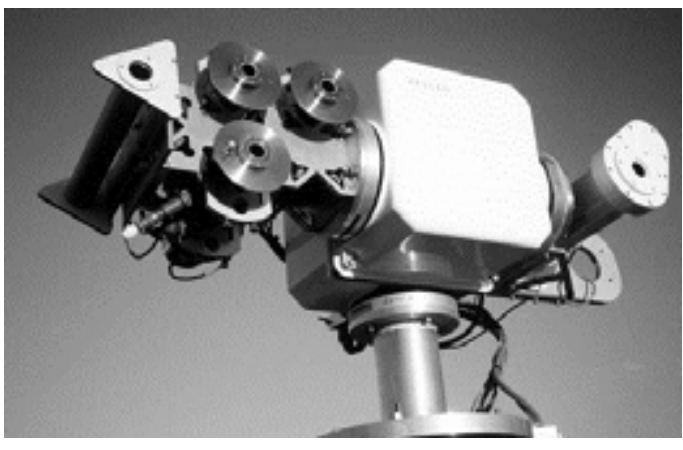

Figure 3.1 Pyrheliometers for measuring direct-normal solar radiation.

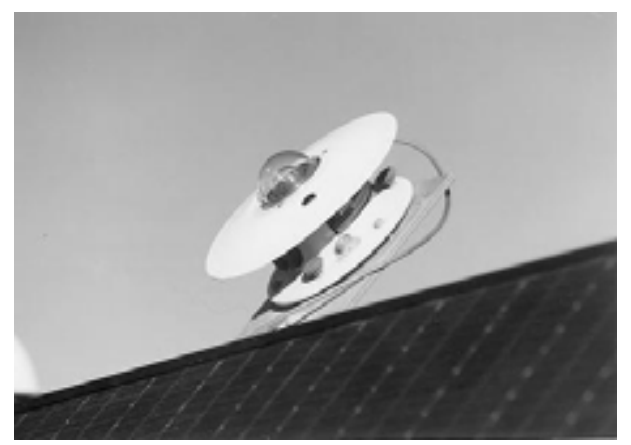

Figure 3.2 Pyranometer for measuring global-hemispherical radiation.

The ratio between the pyranometer output signal (measured in microvolts) and the intensity of the solar power flux (measured in watts per square meter) is known as the calibration factor. NREL's Measurements and Instrumentation Team developed Broadband Outdoor Radiometer Calibration (BORCAL) procedures to characterize and calibrate pyrheliometers and pyranometers. These procedures refined and improved our Radiometric Calibration (RADCAL) techniques. The vehicle for implementing BORCAL data collection, reporting, and data archiving is our Radiometer Calibration and Characterization (RCC) software, developed by the Measurements and Instrumentation Team [10-15] .

Members of the Measurements and Instrumentation Team have worked with the U.S. Department of Energy (DOE) Atmospheric Radiation Measurement Program (ARM), National Aeronautics and Space Administration (NASA) Earth Observing System (EOS) Validation Program, World Meteorological Organization (WMO) Baseline Surface Measurement Network (BSRN), and National Oceanic and Atmospheric Administration (NOAA) Solar Radiation Research Branch (SRRB) to identify, characterize, and reduce sources of error and uncertainty in broadband shortwave radiation calibrations and measurements 


\subsection{WRR Traceability: NPC 2004}

As reported in the Midyear Progress report, we supported the NREL Pyrheliometer Comparison (NPC) September 23 - October 3, 2004 to confirm the stability of NREL reference radiometers for broadband calibrations, and transfer WRR to participating radiometers, according to WMO protocols [16-18] . Individual instruments are compared to a transfer standard group (TSG) of absolute cavity radiometers that participated directly in IPCs, sponsored by the WMO. Twenty-seven cavity radiometers participated, including instruments for the FSEC, U.S. DOE ARM, NASA Langley Research Center, and NOAA. Pooled standard deviation of the TSG radiometers (with four from NREL) was $0.06 \%$, confirming excellent stability of the NREL solar radiometric references.

Results were deduced from the data collected over the period of the 2004 NPC and used to produce ISO-compliant calibration certificates for all participants. The writing of a final report fully documenting the NPC was in progress as of March 2005. The final version of the formal report will be posted on the Solar Radiation Research Laboratory overview website page when completed. A summary of the World Radiation Reference reduction factors derived for all participants is shown in Table 3.1 of the midyear progress report. Table 3.1 below summarizes the results for the NREL TSG and Reference cavity radiometers.

In short, the standard deviations of the mean WRR reduction factors for all participants (excepting AHF30494) were less than $0.08 \%$, and the $95 \%$ confidence interval for the uncertainty in the transfer of WRR to participants was less than or equal to $\pm 0.35 \%$ with respect to SI units, with the exception of AHF30494 (at 0.46\%). 
Table 3.1. Summary Results for NPC 2004 NREL Reference Cavity Radiometers.

\begin{tabular}{|c|c|c|c|c|}
\hline Cavity Serial & $\begin{array}{c}\text { WRR Transfer } \\
\text { Factor }\end{array}$ & $\begin{array}{c}\text { \% Standard } \\
\text { Deviation }\end{array}$ & $\begin{array}{c}\text { Number of } \\
\text { readings }\end{array}$ & $\begin{array}{c}\text { 95\% confidence } \\
\text { Uncertainty }\end{array}$ \\
\hline AHF28968* $^{*}$ & 0.99870 & 0.00 & 1180 & 0.32 \\
\hline AHF29220* $^{*}$ & 0.99865 & 0.03 & 1180 & 0.32 \\
\hline AHF30713 $^{*}$ & 0.99856 & 0.04 & 1180 & 0.32 \\
\hline TMI68018* $^{*}$ & 0.99830 & 0.06 & 1180 & 0.32 \\
\hline AHF23734 $^{\boldsymbol{*}}$ & 0.99886 & 0.03 & 1169 & 0.33 \\
\hline ATMI68017^^$^{\boldsymbol{\wedge}}$ & 1.00043 & 0.07 & 618 & 0.35 \\
\hline ATM69036 $^{\boldsymbol{N}}$ & 1.00161 & 0.05 & 548 & .034 \\
\hline
\end{tabular}

* NPC 2004 NREL Transfer Standard Reference Group Participated in WMO IPC IX.

- NREL NCPV National Center for Photovoltaics Reference Cavity Radiometer Test \& Measurements Group

${ }^{\text {A }}$ NREL automated Technical Measurements Instruments radiometer check standards

\subsection{WRR Traceability, Participation in IPC X}

In order to maintain traceability of NREL reference cavity radiometers to the WRR, we participate in the WMO International Pyrheliometer Comparisons, conducted every 5 years at the World Radiation Center (WRC) in Davos, Switzerland. Table 3.2 summarizes the IPC events NREL has participated in since 1980 (IPC V). After the 1985 IPC VI, the NREL TMI 67814 was put on permanent loan to WRC as a representative instrument for Technical Measurements Inc. manufacturer, and it became a member of the World Standard Group (WSG) of cavity radiometers defining the WRR scale.

Table 3.2 History of NREL Participation in IPC Events.

\begin{tabular}{|c|c|c|}
\hline IPC Event & NREL Reference Radiometer(s) & Performance \\
\hline IPC V 1980 & TMI 67814, TMI 68018 & Std Dev 0.04\% \\
\hline IPC VI 1985 & TMI 67814 & Std Dev 0.09\% \\
\hline IPC VII 1990 & $\begin{array}{c}\text { TMI 68018, TMI69036, } \\
{[\text { TMI 67814] }}\end{array}$ & $\begin{array}{c}\text { Mean Std. Dev. all NREL } \\
\text { Instruments 0.095\% }\end{array}$ \\
\hline IPC VIII 1995 & $\begin{array}{c}\text { TMI68018, HF28968; HF29220, } \\
{[\text { TMI 67814] }}\end{array}$ & $\begin{array}{c}\text { Mean Std dev all NREL } \\
\text { instruments 0.10\% }\end{array}$ \\
\hline IPC IX 2000 & $\begin{array}{c}\text { HF 28968, HF 29220, } \\
\text { HF 30713 } \text { TMI 68018, [TMI 67814] }^{*}\end{array}$ & $\begin{array}{c}\text { Mean Std dev of all NREL } \\
\text { Instruments } 0.06 \%\end{array}$ \\
\hline
\end{tabular}

* As of IPC VII, TMI 67814 on permanent loan to WRC as part of World Standard Group (WSG) of cavity radiometers constituting the definition of the World Radiometric Reference Scale 


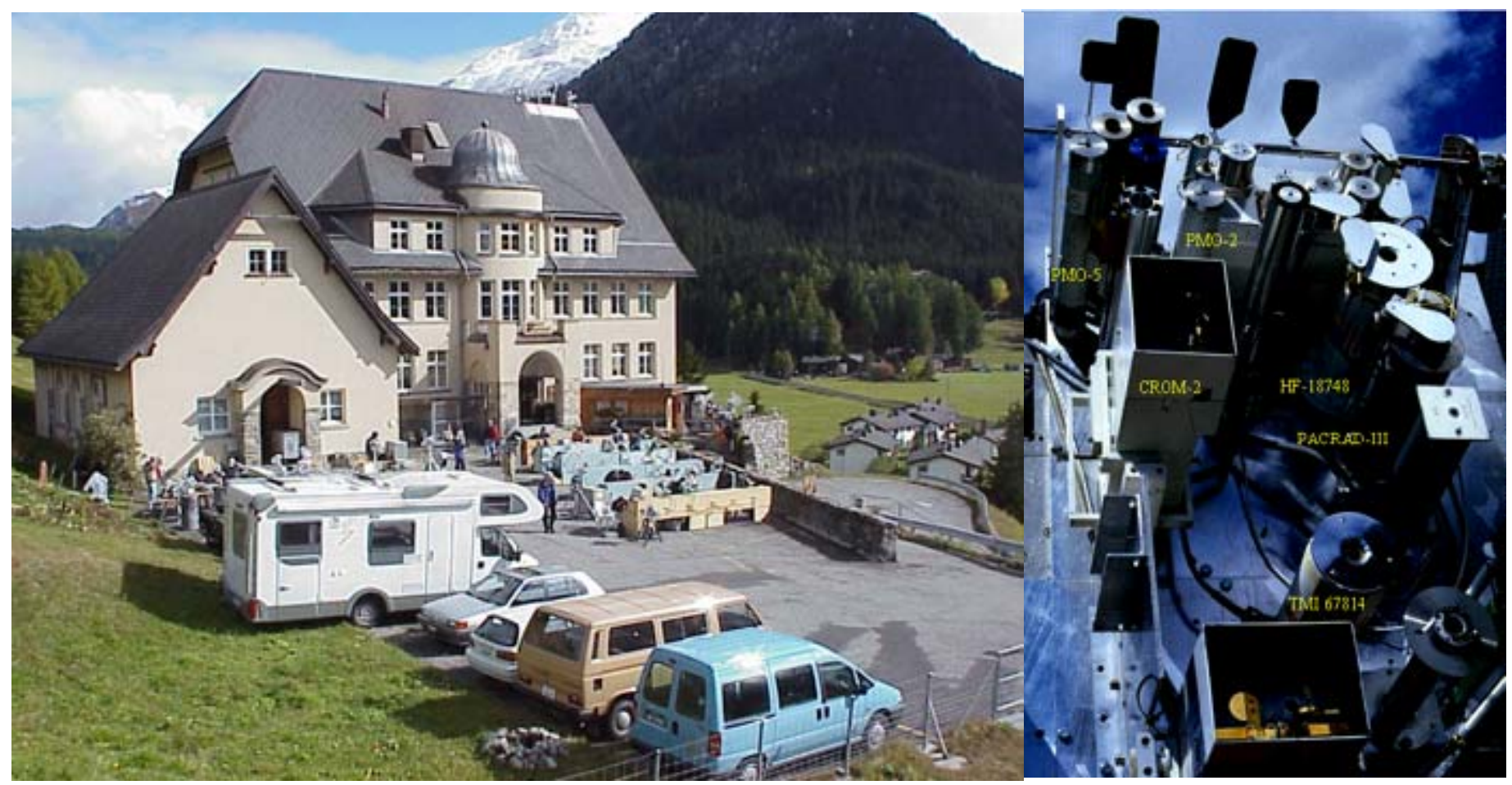

Figure 3.3 IPC meeting site, WRC/PMOD Davos, Switzerland, (left) and World Standard Group (WSG) of absolute cavity radiometers (including NREL TMI 67814)

Part of the task activities identified at the end of FY 05 was to obtain approval for participation and prepare for IPC X, to be held September 29 to October 19, 2005 in Davos. The task contributes approximately $1 / 3$ of the cost of shipping instruments and travel expenses, in conjunction with an NREL Technical Partnership agreement with the DOE ARM program, and the internal NREL Metrology Task. We prepared Foreign Travel Requests in August, 2005 for the September-October 2005 travel period, conducted an intercomparison of the cavity radiometers before packing them, and packed and shipped the radiometers and ancillary equipment to Davos. The radiometers, ancillary equipment, and measurements team arrived in Davos September 27th, 2005 to begin participating in the comparison. Figure 3.3 shows the typical participation setup at the Physical Meteorological Observatory, Davos (PMOD) where the intercomparisons are conducted, and the WSG group of reference radiometers embodying the WRR. 


\subsection{Characterizing Solar Radiometer Uncertainty and Performance}

\subsubsection{Introduction}

Total (global) G, Direct beam, B, Diffuse Sky (scattered), D,

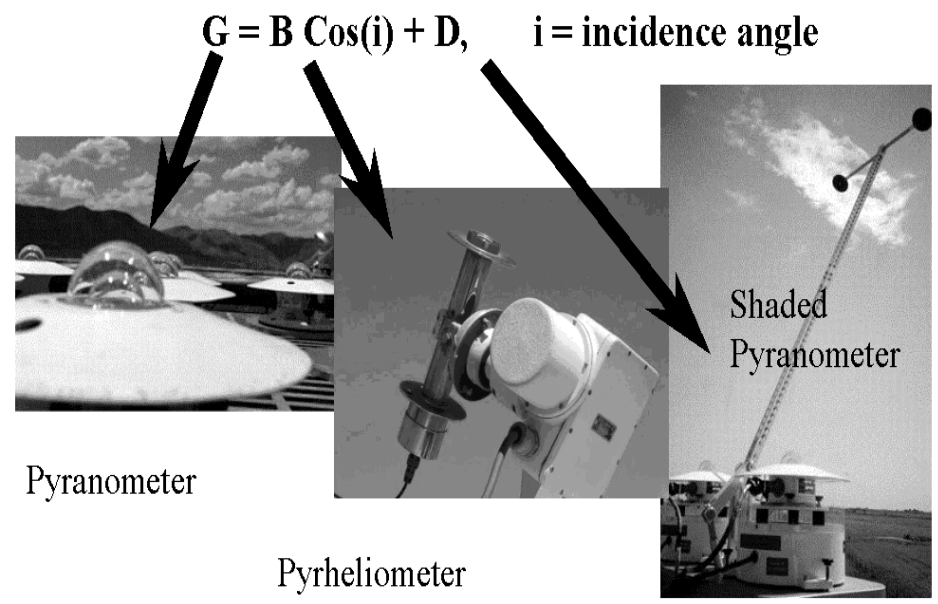

Figure 3.4 Solar radiation measurement instruments and the components they measure.

Several types of detectors are used for pyrheliometer and pyranometer instruments (shown in Figure 3.4), including silicon cells and thermal detectors such as resistance thermometers and thermopiles. We conducted research leading to a revised understanding of the sources of uncertainty in instruments based upon thermopiles, under quartz or Schott WG295 glass domes that transmit shortwave radiation from $295 \mathrm{~nm}$ to $2800 \mathrm{~nm}$. We also conducted a year-long study of the influence of environmental conditions (temperature fluctuations, wind speed, irradiance fluctuations) on the performance of normal incidence pyrheliometers. We characterized the performance of an Indoor Calibration System (ICS) for pyranometer calibrations, and designed and integrated a new data acquisition system for broadband outdoor radiometer calibrations into NREL. We incorporated new knowledge into revisions of the ASTM standard methods for calibrating solar radiometers, and submitted the revisions for ASTM Ballot action. [19, 20].

\subsubsection{Thermal Offsets in Thermopile Pyranometers}

Responsivity (Rsd) of a diffuse-measuring reference pyranometer is derived in a shadeunshade calibration using $\mathrm{Rsd}=(\mathrm{U}-\mathrm{S}) /[\mathrm{B} * \operatorname{Cos}(\mathrm{z})]$, where $\mathrm{U}$ and $\mathrm{S}$ are the unshaded and shaded output voltages from the sensor, $\mathrm{z}$ is the zenith angle, and $\mathrm{B}$ is measured by an ACR (shown schematically in Figure 3.5. Procedures for this calibration are described in ASTM G-167 [20] . NREL developed shade-unshade pyranometer calibrations using an average responsivity at $45^{\circ}$ zenith angle for three instrument azimuth angles to integrate over geometric response variations. This procedure was modified to include a continuously shaded, or control pyranometer, and reduce the azimuth rotation angles to $60^{\circ}$. One may then fit responsivities to the zenith angle, $\operatorname{Rs}(\mathrm{z})$, to compute six $\operatorname{Rs}\left(45^{\circ}\right)$. 
The mean of these responsivities is used for the shaded pyranometer in the component summation calibration technique [13] .

Studies of solar radiation instrumentation in climate research, as in the World Climate Change Research Program BSRN and others characterized thermal "zero offsets" in thermopile pyranometers with all-black sensors measuring diffuse radiation. Offsets produce negative engineering data at night, and clear sky diffuse irradiances lower than pure Rayliegh scattering theory predicts. The offsets occur as cold junctions of the thermopile are in a different thermal environment than the absorbing junctions.[14, 21 23]

In section 3.2 of the midyear progress report, we reported experimental and model results that characterize the relationship of shortwave (less than $2800 \mathrm{~nm}$ in wavelength) solar radiometer responsivity to longwave (infrared radiation greater then $3000 \mathrm{~nm}$, or 3 microns, in wavelength). We used the MODTRAN [24] atmospheric spectral radiative transfer code to compute shortwave and longwave (infrared, $3000 \mathrm{~nm}$ to $10000 \mathrm{~nm}$ ) direct beam and sky (diffuse) radiation. The IR signal beyond $3000 \mathrm{~nm}$ is present in both the shaded and unshaded state of a pyranometer. The thermal exchange between the sky and sensor/domes cannot be the same for shaded and unshaded conditions. For blackand-white sensors, the reference and absorbing thermopile junctions are in a similar thermal environment. These radiometers have lower $\left(\sim 1\right.$ to $\left.2 \mathrm{~W} / \mathrm{m}^{2}\right)$ offsets and produce more accurate diffuse measurements.

\subsubsection{Other Spectral Errors}

There is an additional spectral affect on the shade-unshade calibration in the diffuse. The diffuse sky radiation has very little energy in the shortwave region from $1000 \mathrm{~nm}$ to 2800 $\mathrm{nm}$, while the direct beam has significant energy in that region (see Figure 3.8).

Therefore, nothing affecting the direct beam total irradiance between $1000 \mathrm{~nm}$ and 2800 $\mathrm{nm}$, such as variations in atmospheric water vapor, affects the shaded pyranometer signal. For the several different direct normal irradiances, the same shaded signal is possible from the pyranometer. MODTRAN modeling of this "spectral mismatch" effect results in errors of about $0.5 \%$ in Rs, for total precipitable water vapor varying from $0.5 \mathrm{~atm}-\mathrm{cm}$ to $3.5 \mathrm{~atm}-\mathrm{cm}$.

The MODTRAN spectral model was used with varying total precipitable water vapor over a reasonable range of $0.5 \mathrm{~atm}-\mathrm{cm}$ to $3.5 \mathrm{~atm}-\mathrm{cm}$, to produce global total and diffuse spectra shown in Figure 3.8. The light areas between the global irradiance plots shows the difference between the low and high water vapor conditions (dark gray $=3.5 \mathrm{~atm}-\mathrm{cm}$ water vapor and white $=0.5 \mathrm{~atm}-\mathrm{cm}$ water vapor filled curves). The changes in the diffuse spectral distribution (bottom white $=3.5 \mathrm{~atm}-\mathrm{cm}$ and gray $=0.5 \mathrm{~atm}-\mathrm{cm}$ filled curves) are minimal. For essentially the same diffuse radiation, varying water vapor content results in changes of up to $0.5 \%$ in shaded-unshade responsivities for both all-black and black-andwhite detector pyranometers with respect to the global reference spectrum.

We also discussed previously the "spectral mismatch" error [25] resulting from differing solar spectra under calibration and field measurement conditions. For a given reference 
spectrum $E_{\text {ref }}(\lambda)$, reference spectral response $S_{\text {ref }}(\lambda)$, test spectrum $E_{\text {test }}(\lambda)$, and device spectral response $s(\lambda)$, the spectral mismatch factor resulting from the deviations of the test device response and the reference spectrum is given by:

$$
M=\frac{\int E_{\text {test }}(\lambda) * s(\lambda) \cdot d \lambda \cdot \int E_{r e f}(\lambda) * S_{r e f}(\lambda) d \lambda}{\int E_{\text {test }}(\lambda) * S_{r e f}(\lambda) \cdot d \lambda \cdot \int E_{r e f}(\lambda) * s(\lambda) \cdot d \lambda}
$$

For the pyranometer calibrations, at each condition (high and low values of water vapor), $\mathrm{E}_{\text {ref }}$ is the global (unshaded) spectrum and $\mathrm{E}_{\text {test }}$ is the diffuse (shaded) spectrum. Low water vapor case produces an $\mathrm{M}$ of 1.002; while the high water vapor case produces an $\mathrm{M}$ of 1.007; giving the relative difference of $100 *(1.007-1.002) / 1.002=0.5 \%$. If spectral conditions deviate significantly from a chosen reference spectrum (say high altitude location with respect to a sea level location), the spectral error may become sitedependant.

\subsubsection{Longwave Responsivity of Shortwave Radiometers}

Experiments conducted with an NREL blackbody (BB) source to characterize thermal "zero offset" signals in thermopile pyranometers with all-black sensors [14] demonstrated that the radiometer output voltage is linear with respect to the NET-IR for all pyranometers. The slope of the straight line fit is the BB responsivity of the pyranometer, $\mathrm{RS}_{\mathrm{bb}}$,

$$
R S_{B B}=\frac{V_{T P}}{E_{b b}-E_{C}}=\frac{V_{T P}}{W_{N E T}}
$$

where:

$-\mathrm{V}_{T P}$ is the thermopile output voltage of the pyranometer, in microvolt

- $\mathrm{W}_{\mathrm{NET}}$ is the NET-IR, in $\mathrm{W} / \mathrm{m}^{2}$

$-\mathrm{E}_{\mathrm{bb}}$ is the $\mathrm{BB}$ radiation, in

$\mathrm{W} / \mathrm{m}^{2}=\sigma^{*} \mathrm{~T}_{\mathrm{bb}}^{4}$, where $\sigma=5.6697 \times 10^{-8-8} \mathrm{Wm}^{-2} \mathrm{~K}^{-4}$, and $\mathrm{T}_{\mathrm{bb}}$ is the BB temperature, in Kelvin

- $\mathrm{E}_{\mathrm{c}}$ is the pyranometer case radiation, in $\mathrm{W} / \mathrm{m}^{2}=\sigma^{*} \mathrm{~T}^{4}{ }_{\mathrm{c}}$, where $\mathrm{T}_{\mathrm{c}}$ is the pyranometer case temperature, in Kelvin. This temperature is measured by either a thermistor that is fitted in the pyranometer case, or a thermistor inside the aluminum mounting plate for the pyranometer.

These results will be incorporated into a revision of the NREL RCC software for BORCAL during FY 2006. 


\subsubsection{Geometric, Environmental, and Equipment Uncertainty}

Additional well-known contributors to radiometer calibration and measurement uncertainty include: the accuracy of the calculation of the zenith angle; the nonLambertian cosine response of the detector surface, temperature coefficients, linearity, thermal electromotive forces (sunshine on connectors), and electromagnetic interference (EMI). Finally, the specification and performance of the data logging equipment (resolution, precision, and accuracy) must be considered [10]. Table 3.3 lists these uncertainties. 
Table 3.3 Uncertainty for Pyranometer Responsivity, 95\% Confidence Interval

\begin{tabular}{lrl} 
TYPE A (Statistical) & UNC(\%) & STD UNC (\%) \\
\hline WRR Transfer & $* 0.200$ & 0.200 \\
Cos $(\mathrm{z})\left(2^{\circ} \mathrm{Z}\right.$ bin) & 0.010 & 0.005 \\
Dif $(2.5 \% \mathrm{D}=>0.25 \%$ Ref.) & 0.125 & 0.063 \\
Temperature $\left(2^{\circ} \mathrm{Z}\right.$ bin) & 0.100 & 0.050 \\
Data Logger Precision & 0.005 & 0.0025 \\
ACR (wind, T) & 0.025 & 0.013 \\
Temp Chg $\left(10^{\circ} \mathrm{C}\right)$ & 0.250 & 0.125 \\
Diff Offset B\&W & 0.125 & 0.063 \\
UUT IR OFFSET & 0.250 & 0.125 \\
EMI/Thermal EMF & 0.010 & 0.005
\end{tabular}

\begin{tabular}{lrl} 
TYPE B & UNC(\%) & STD UNC(\%) \\
\hline Logger Bias (9 uV/10 mv) & $* 0.090$ & 0.090 \\
WRR Std U95 & $* 0.300$ & 0.300 \\
Cos $(\mathrm{z}) \mathrm{Z}<89 \mathrm{deg} ; 2^{\circ}$ bin & 0.010 & 0.005 \\
Temperature (2 ${ }^{\circ} \mathrm{Z}$ bin) & 0.100 & 0.050 \\
ACR Bias (M,wind, T) & 0.025 & 0.013 \\
Temp B (event to event) $10^{\circ} \mathrm{C}$ & 0.250 & 0.125 \\
Diff Offset B\&W & 0.125 & 0.063 \\
UUT IR OFFSET & $* 0.625$ & 0.625 \\
Spectral error & $* 0.500$ & 0.250 \\
EMI/Thermal EMF & 0.010 & 0.005
\end{tabular}

\begin{tabular}{lrc} 
TOTAL & UNCERT & STD UNCERT \\
\hline TYPE A & 0.455 & 0.286 \\
TYPE B & 0.910 & 0.872 \\
COMBINED & $\mathbf{1 . 0 1 7}$ & $\mathbf{0 . 9 1 8}$
\end{tabular}

\begin{tabular}{ll} 
EFFECTIVE DEG. OF FREEDOM & $>100$ \\
COVERAGE FACTOR (k) & 2 \\
EXPANDED UNCERTAINTY & $\mathbf{1 . 8 4 \%}$ \\
\hline
\end{tabular}




\subsubsection{Responsivity Functions}

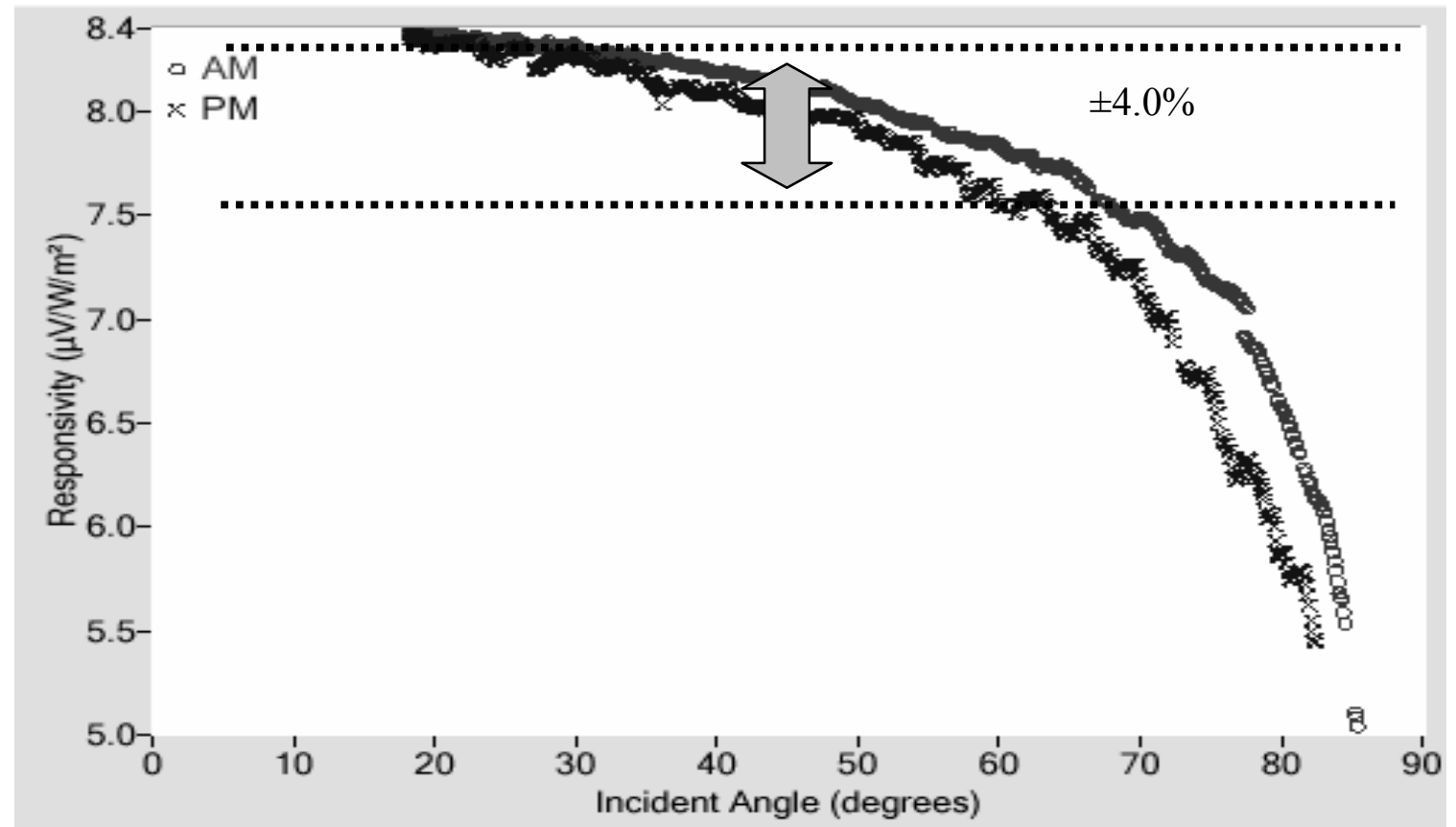

Figure 3.5. Pyranometer responsivity versus solar zenith angle. Dotted lines are $+4 \%$ and $4 \%$ away from mean $\operatorname{Rs}\left(45^{\circ}\right)$.

Rather than evaluate offsets in the calibration (or measurement) process, a responsivity function derived from calibration data with the offsets embedded in the result should be used to retrieve the most accurate irradiance from a pyranometer. Figure 3.5 shows the responsivity of a pyranometer versus zenith angle using NREL component summation calibration. The uncertainty in each pyranometer calibration responsivity point in Figure 3.5 is summarized in Table 3.3. The expanded uncertainty for each point in the curves of Figure 3.5 is about $1.8 \%$, with coverage factor $k=2$. This is the smallest uncertainty that can be expected of a pyranometer, under conditions identical to the calibration conditions at a specific zenith angle. To apply corrections for a specific zenith angle, a functional approximation has been developed of the form $[11,12]$ :

$\operatorname{Rs}(z)_{A M / P M}=\sum_{i=0}^{i=46} a_{i} \bullet \operatorname{Cos}^{i}(z)$

where the $a_{i}$ are 46 coefficients for each morning and afternoon set of $z$.

With this approach, uncertainty of about $\pm 1.8 \%$ in measured pyranometer data at any zenith angle during clear conditions can be achieved. Under cloudy conditions, this uncertainty may be larger. For any single responsivity, Rs(zo), the uncertainty in a measurement of global irradiance changes as the difference between Rs(zo) and Rs(m) changes. The uncertainty may grow to more than $10 \%$ for zenith angles sufficiently separated. In the field, further sources of uncertainty arise, such as differing (usually lower resolution) data logging, cleanliness, and even climatological conditions, which must be considered in addition to the calibration uncertainty computed in Table 3.3. 


\subsubsection{Pyranometer Corrections from Field Data}

If a measurement station is equipped to measure global total horizontal, direct beam, and accurate diffuse irradiances, one can use clear day data to perform an in-situ characterization of the responsivity variation of a pyranometer throughout the year. A recent journal article produced by NREL [26] describes the technique, which was summarized in the midyear progress report, section 3.2.5.

Cloudless days were used to obtain data where the instruments (pyrheliometer, pyranometer, diffuse pyranometer, and where available, net infrared data) were operating. The days are grouped by month and a random sample of three clear days were taken from each month. A collection of 31 sample days composed a mock year of twelve three-day "months". Global total pyranometer raw signals, S, are obtained by dividing irradiance by the single calibration factor used to compute the archived data. Reference global irradiances were calculated from the diffuse and direct beam instrument using the summation equation: $\mathrm{G}_{\mathrm{r}}=\mathrm{B} \operatorname{Cos}(\mathrm{z})+\mathrm{F}$. "Raw" responsivities, Rs, are then computed from $\mathrm{Rs}=\mathrm{S} / \mathrm{G}_{\mathrm{r}}$. Figure 3.6 shows the resulting annual variation in Rs over a year (dark lines).

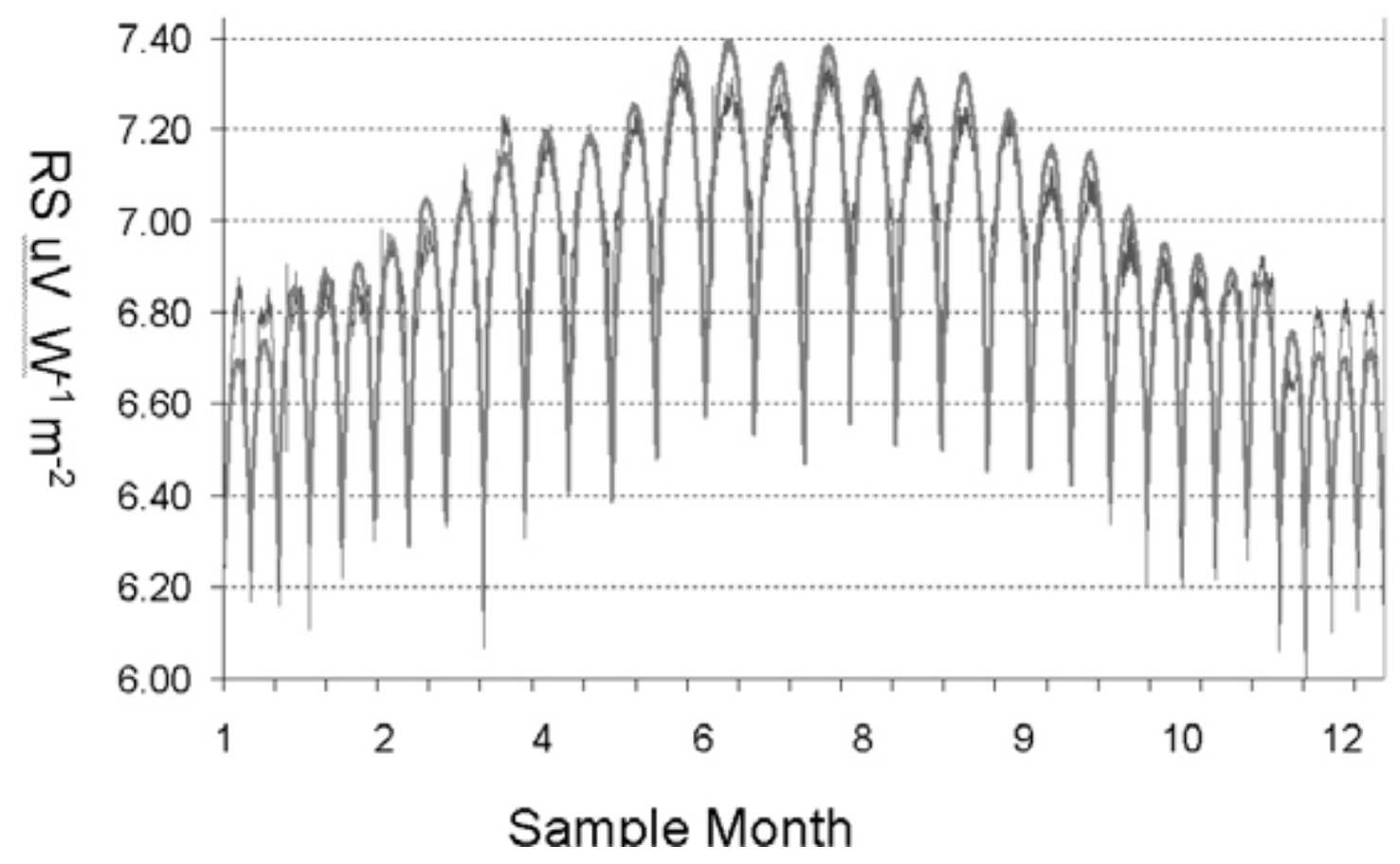

Figure 3.6. Raw Rs varies daily and yearly due to variations in zenith angle throughout the day and year respectively (dark jagged curve). Fit of Rs function of $\cos (Z), \cos (2 \pi D / 365)$ shown as smooth gray curve.

Figure 3.7 shows typical data for such a calibration. There are national and international standards documents that describe the procedures for calibration of field pyrheliometers from primary (absolute cavity) pyrheliometers and reference pyrheliometers [20,27] . 


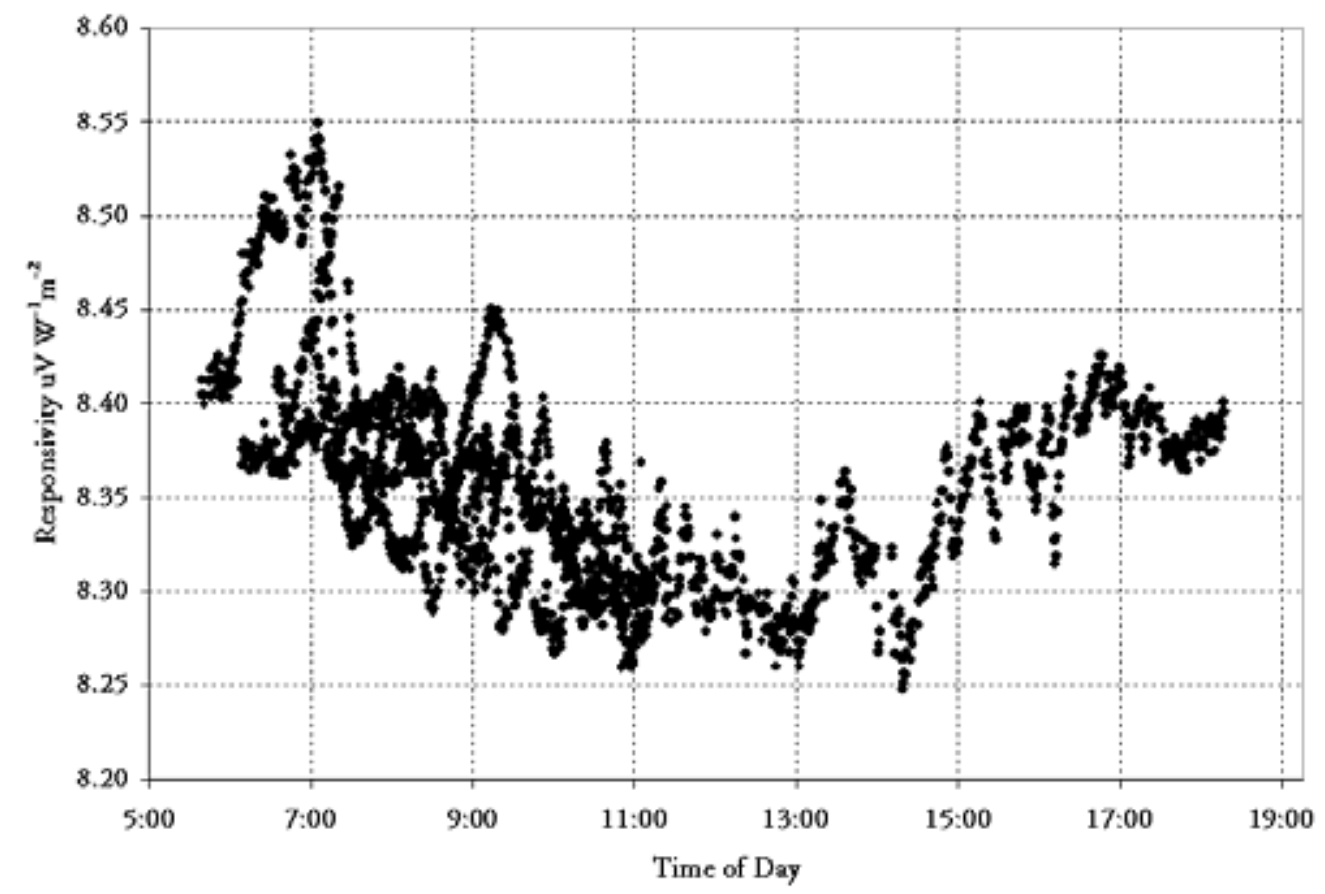

Figure 3.7 Pyrheliometer calibration data showing the variation in responsivity (ratio of signal to reference irradiance) throughout several days. Calibration factor may be computed several ways: average of all data, or average of data over selected interval or zenith angle range.

The shape of the response function seen in Figure 3.7 is a current topic of research. Possible explanations are the different fields of view of the reference $\left(5.0^{\circ}\right)$ and test $\left(5.7^{\circ}\right)$ pyrheliometers, environmental influences (ambient temperature, wind speed, and direction), and test instrument design (thermal gradients between detector and reference thermocouples). Table 3.4 lists the present sources of uncertainty and estimated total uncertainty in current RCC calibrations of pyrheliometers.

Table 3.4. Uncertainty for Pyrehliometer Responsivities $95 \%$ confidence interval

\begin{tabular}{lrc} 
TYPE A (Statistical) & UNC $(\%)$ & STD UNC $(\%)$ \\
\hline WRR Transfer & $* 0.200$ & 0.200 \\
Temp Response UUT & 0.500 & 0.050 \\
Data Logger Precision & 0.005 & 0.0025 \\
Linearity (empirical) & 0.200 & 0.100 \\
ACR (wind, T) & 0.025 & 0.013 \\
Tracking variations & 0.250 & 0.125 \\
Spectral (window) & $* 0.500$ & 0.500 \\
EMI/Thermal EMF & 0.010 & 0.005 \\
& & \\
TOTAL & UNCERT(\%) & STD UNCERT(\%) \\
TYPE A & 0.802 & 0.615 \\
TYPE B & 0.851 & 0.504 \\
COMBINED & $\mathbf{1 . 1 6 9}$ & $\mathbf{0 . 9 1 8}$
\end{tabular}

\begin{tabular}{lrl} 
TYPE B & UNC(\%) & STD UNC(\%) \\
\hline Logger Bias (9 uV/10 mv) & $* 0.090$ & 0.090 \\
WRR Std U95 & $* 0.300$ & 0.300 \\
Temp Response UUT & 0.500 & 0.250 \\
ACR Bias (M,wind, T) & 0.025 & 0.013 \\
Temp B (event to event) $10^{\circ}$ & 0.250 & 0.125 \\
Spectral error & $* 0.500$ & 0.500 \\
Tracking Bias & 0.250 & 0.0125 \\
EMI/Thermal EMF & 0.010 & 0.005 \\
& & \\
EFFECTIVE DEG. OF FREEDOM & $>100$ \\
COVERAGE FACTOR (k) & 2 \\
EXPANDED UNCERTAINTY & $\mathbf{1 . 5 9 \%}$
\end{tabular}


With deployment to the field, pyrheliometer data becomes subject to additional tracking and window (cleanliness) issues, differing data logger specifications, etc., requiring additional analysis specific to the deployment to arrive at a total measurement uncertainty.

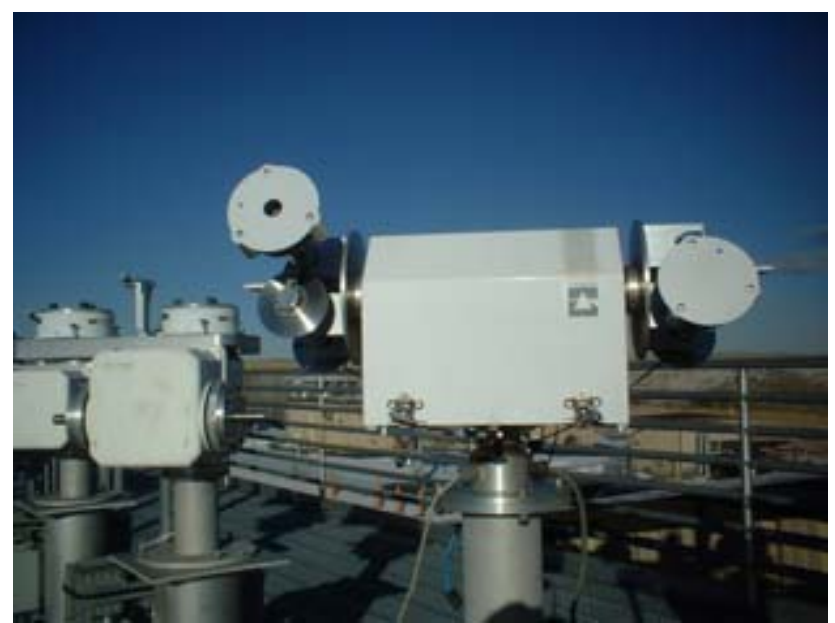

Figure 3.8. Pyrheliometers in three shaded configurations for studying environmental influences on pyrheliometer offset errors.

One investigation involves looking at pyrheliometers with different configurations of shaded physical elements and recording the "dark" signals. Figure 3.8 is a photograph of a setup where one pyrheliometer has only the window/aperture shaded (bottom left), another has the entire front flange of the pyrheliometer shaded (right) and a third has only the flange shaded, with an aperture to allow the direct beam to reach the receiver (top left). As described in the midyear progress report, the "window only" shaded pyrheliometer has a considerably larger offset ( 5 microvolts to 20 microvolts) than the "flange+ window" shaded instrument ( 1 to 5 microvolts). Correlations of the window shaded only offset signals with environmental data (direct beam irradiance, B; rate of change of ambient temperature per ten minute interval, $\Delta \mathrm{T}$; and wind speed, $\mathrm{W}$ ) were investigated throughout FY 2005.

Five different models were constructed to try and estimate the pyrheliometer zero drift $(\mathrm{Z})$ as a function of beam irradiance (B), Wind speed, $(\mathrm{W})$, and rate of change of temperature $(\mathrm{DT} / \mathrm{Dt})$ [for $\mathrm{Dt}=10$ minutes $]$. The models included (a) independent parametric fits of $\mathrm{Z}$ vs each variable, (b) multilinear regression with and (c) without a constant term, and (d) a 2-component - daytime / nighttime - multilinear regression, and (e) a 3-component -nighttime/day hi wind/day low wind regression model. The histograms below (Figure 3.9) are of the zero drift data for the six month period of the test, and of the MODELED zero drift signal for each of the models. The two best candidates to replicate the distribution of the measured offset data (top left panel) are the "combined" model (top right) and the "composite" model (bottom right). Table 3.5 shows the mean bias error for each model, indicating the composite model performs the best, in terms of mean bias error, by at least a factor of 10 . 
Table 3.5. Model Performance for Five Models Estimating Pyrheliometer Zero Offset Voltage

\begin{tabular}{|c|c|c|c|c||c|}
\hline Parameter & Parametric & $\begin{array}{c}\text { Day } \\
\text { Night }\end{array}$ & $\begin{array}{c}\text { Multilinear } \\
\text { no } \\
\text { Constant }\end{array}$ & $\begin{array}{c}\text { Night } \\
\text { Dagh/low } \\
\text { high }\end{array}$ & Multilinear \\
Constant \\
\hline Count & 259190 & 259190 & 259190 & 259190 & 259190 \\
\hline Mean & $\mathbf{0 . 0 0 1 8 0}$ & - & $\mathbf{0 . 0 1 1 5}$ & $\mathbf{0 . 0 0 0 2}$ & $\mathbf{0 . 0 2 3 8}$ \\
\hline StDev & 0.0233 & 0.0251 & 0.0251 & 0.02206 & 0.0188 \\
\hline
\end{tabular}
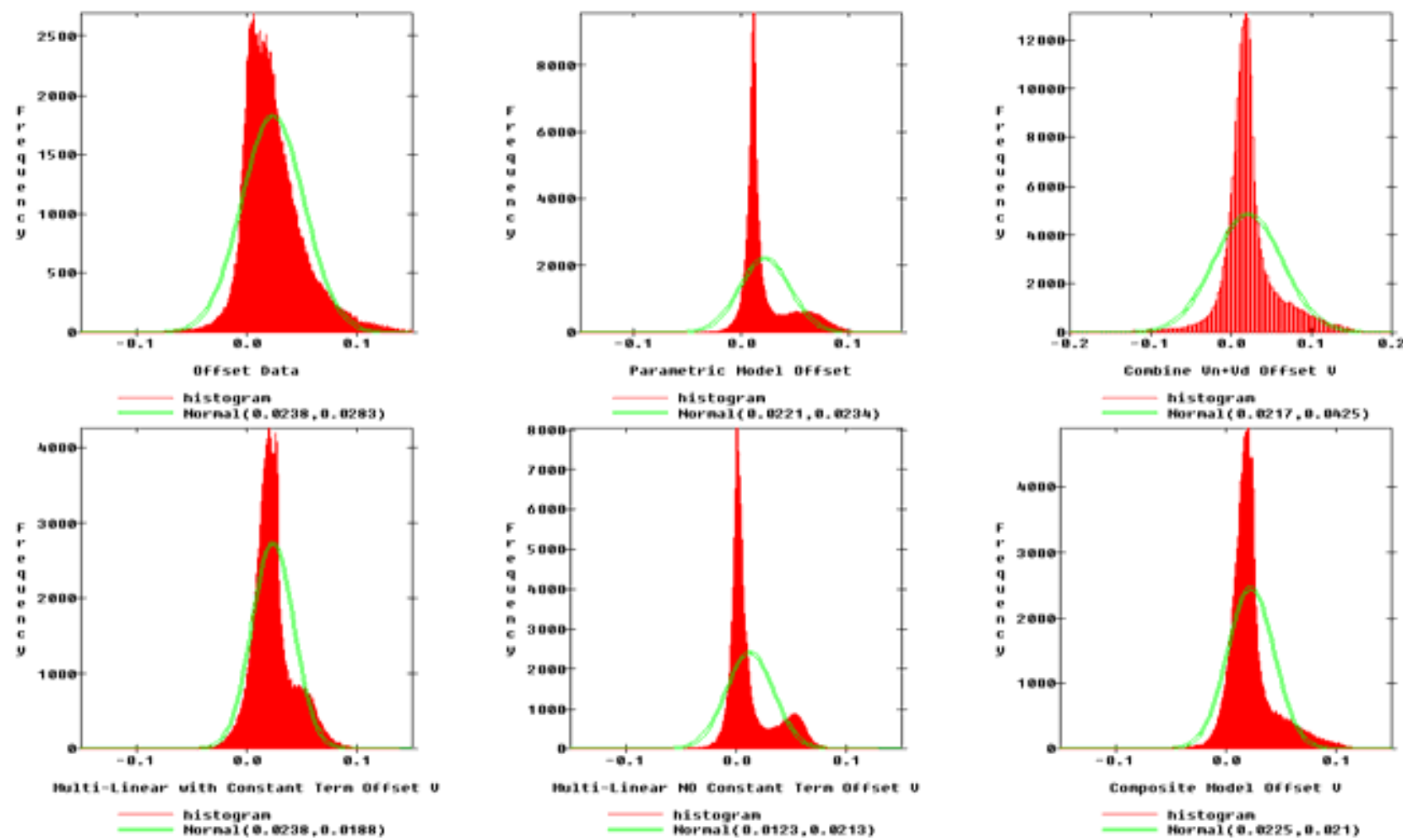

Figure 3.9. Histograms of pyrheliometer zero offsets for measured (top left) shaded window pyrheliometer, and 5 models. Numbers is parenthesis are mean and standard deviation of the data sets, and the green double line is a normal distribution with the same mean and standard deviation.

Further tests on unshaded pyrheliometers were performed outdoors by looking at the effect a high speed fan (simulating high wind speeds) has on pyrheliometer voltage. Figure 3.10 shows a fan configured to ventilate an unshaded Eppley model NIP pyrheliometer monitoring the direct beam. 
During this clear day test, natural wind speeds were below 2 meters per second, $\left(\mathrm{ms}^{-1}\right)$ quartering from the south east. Two other pyrheliometers were continuously monitoring the beam radiation as well. The fan was cycled on and off, and the effect on the pyrheliometer voltage monitored. With the fan on, the air velocity in the neighborhood of the radiometer is 6 to $7 \mathrm{~ms}^{-1}$. Data were recorded as 1 minute averages of 3 second samples of the voltages.

Figure 3.11 shows that as soon as the fan is turned on or off, the pyrheliometer output voltage is affected by being slightly reduced. A further test was conducted by cycling a fan on and off at hourly intervals throughout a clear day. Two nearby pyrheliometers were undisturbed, and monitored the direct beam as well. The difference between the undisturbed and ventilated fan was computed, and hourly averages of the differences computed. Figure 3.12 shows the minute by minute and hourly comparison of the differences.

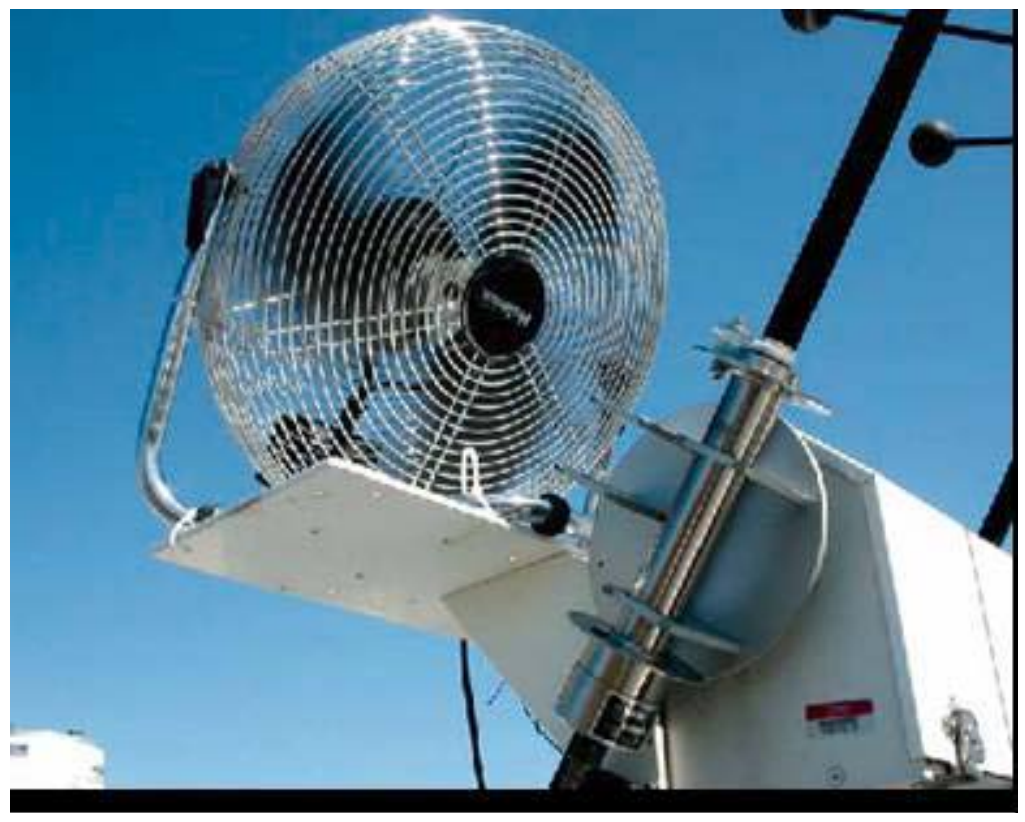

Figure 3.10 Outdoor pyrheliometer wind speed test with high speed fan. 


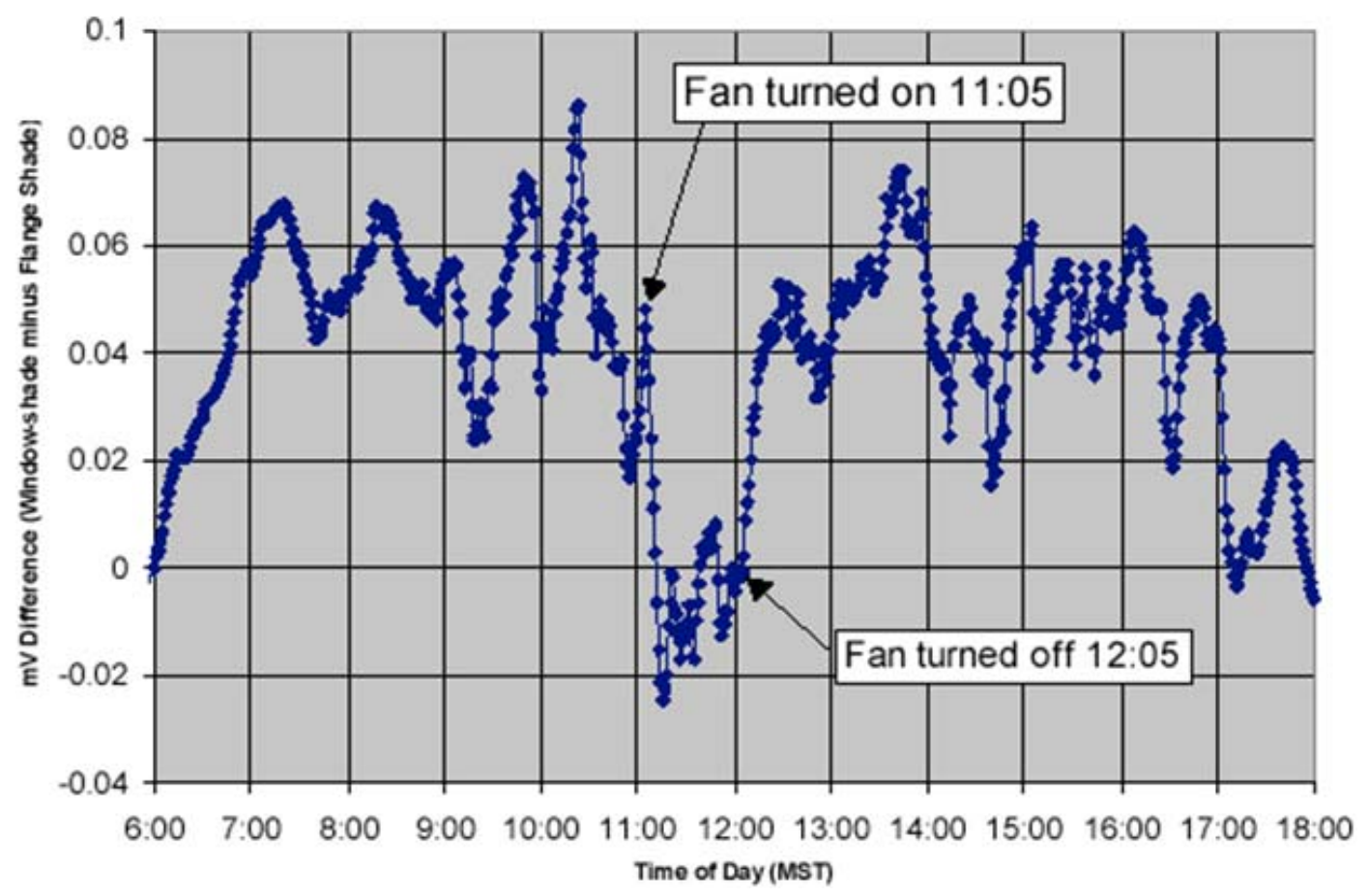

Figure 3.11. Response of unshaded pyrheliometer to increased air flow of $6 \mathrm{~ms}^{-1}$ to $7 \mathrm{~ms}^{-1}$ from nearby fan.

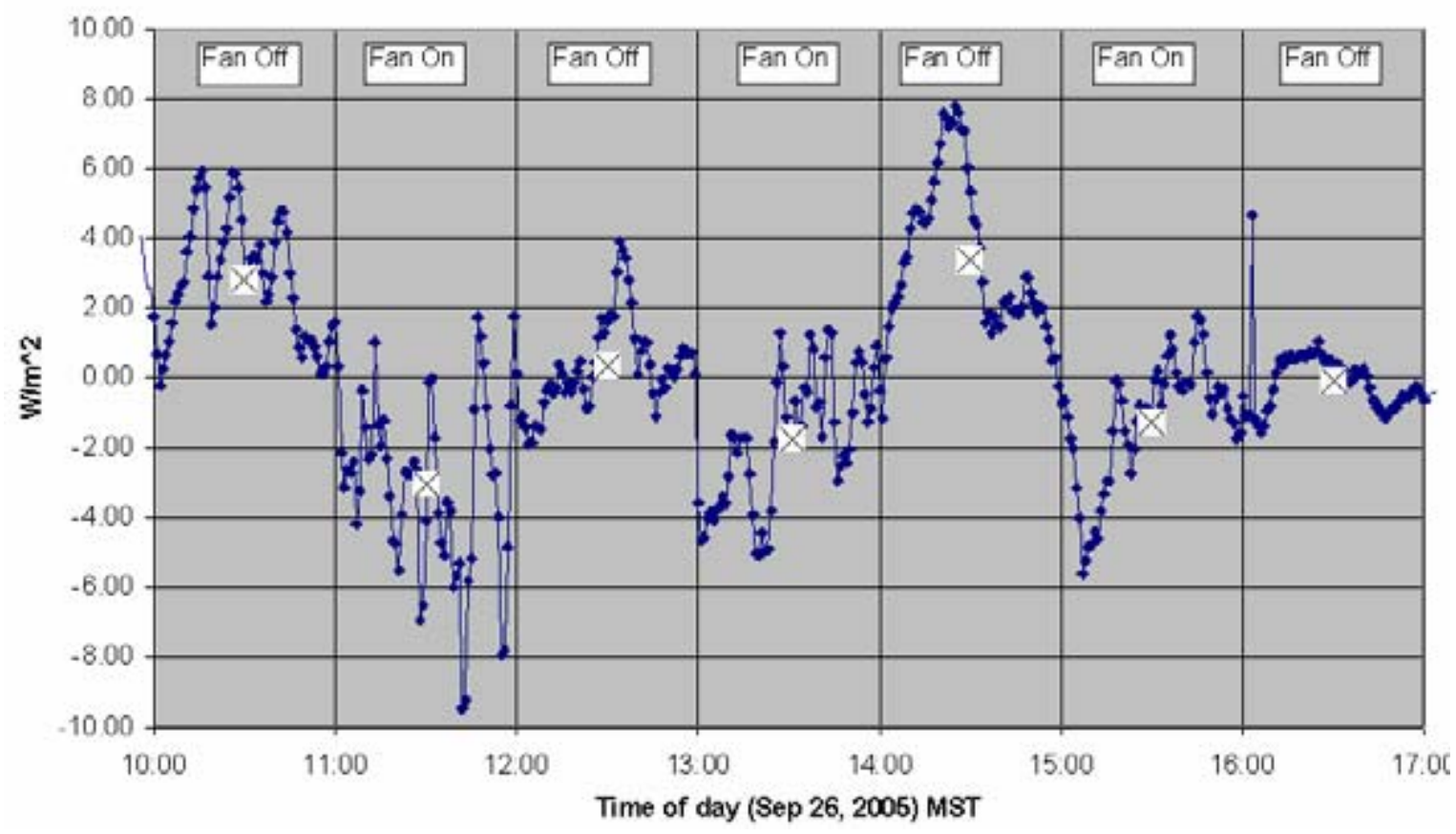

Figure 3.12. One-minute (dotted line) and hourly average ( $X$ in box) difference in irradiance between two pyrheliometers, one ventilated at hourly intervals, the other undisturbed. 
A statistical analysis of the difference between the fan-on and fan-off hourly mean differences shows that the ventilation had a statistically significant effect on the ventilated pyrheliometer signal with a confidence level of 99.95\%. [28]

Further analysis, and a journal article summarizing our findings and their significance will be published in FY 06.

\subsubsection{Revisions to ASTM Radiometer Calibration Standards}

As reported in the midyear progress report, the task participates in several consensus standards activities to support the PV industry in developing quality products with substantiated claims of performance. We provide technical expertise on radiometric measurements to ASTM committee E44 on Solar, Geothermal, and Alternative Energy Sources, G03 on Reliability and Durability, and the International Lighting Commission (CIE) Technical Committee TC-72 on Solar Spectral Distributions. As a result of the research findings discussed above, we proposed withdrawing two obsolete standards, and developed revisions to two ASTM Standards and presented them for committee review at the January 2005 meeting of committee G03. Since the midyear progress report, and additional standard was identified for revision and the revision completed.

The committee withdrew the two obsolete standards:

E913-82(1999) Standard Method for Calibration of Reference Pyranometers with Axis Vertical by the Shading Method

E941-83(1999) Standard Test Method for Calibration of Reference Pyranometers with Axis Tilted by the Shading Method and the three standards selected for revision were::

G167-00 Standard Test Method for Calibration of a Pyranometer Using a Pyrheliometer

E816-95 Standard Test Method for Calibration of Pyrheliometers by Comparison to Reference Pyrheliometers

E824-94 Standard Test Method for Transfer of Calibration from Reference to Field Radiometers.

We accomplished the first draft revisions in time for ballot ASTM main committee before the June 24-26 2005 committee meeting in Pittsburg, PA. The result of the initial ballot on the first two revised standards were that 16 negative items and editorial comments were identified, and needed to be corrected; then the two balloted standards needed to be submitted, along with the first draft revision of the third standard, by August 8,2005 . Revisions to all three standards were accomplished, addressing the negatives and 
comments identified for the first two standards. All three standards were submitted for ballot on time, and were balloted between August 16 and September 16, 2005, as shown in Figure 3.13, as screen image of the ASTM ballot website.

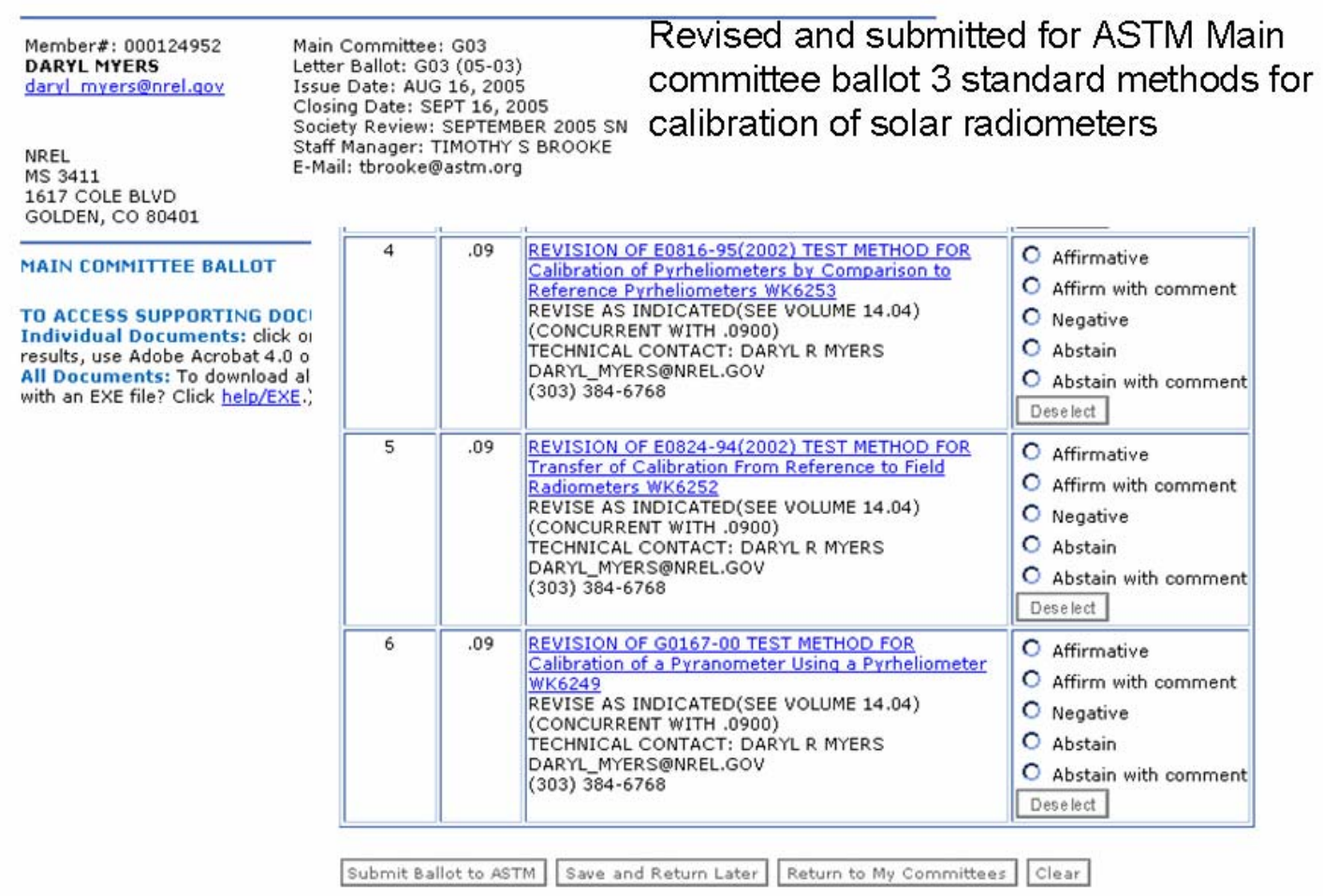

Figure 3.13 ASTM Ballot website screen image showing three standards revised under the leadership of this task.

Any further negative vote on the ballot actions must be addressed and deemed persuasive or non-persuasive by the committee; after which time further revisions may be made, or the approved standards proceed to full committee ballot.

The proposed modifications to the ASTM standard shade-unshade pyranometer calibration determine an average responsivity at $45^{\circ}$ zenith angle for three instrument azimuth angles. This results in integration over geometric response variations [13] A further modification includes a continuously shaded, or control pyranometer, and $60^{\circ}$ rotation angles. Regression fits of responsivities to zenith angle, $\operatorname{Rs}(\mathrm{z})$ determine six values of $\operatorname{Rs}\left(45^{\circ}\right)$, the mean of which is the calibration value for the reference diffuse (shaded pyranometer) for use in a component summation calibration. The Solar Radiometric and Metrology task has demonstrated that with the modified shade-unshade technique, clear sky diffuse irradiance can be measured with an uncertainty of $\pm(3 \%$ of reading $+1.0 \mathrm{Wm}^{-2}$ ). For typical clear sky calibration conditions, the diffuse irradiance is on the order of $10 \%$ of the total global hemispherical irradiance. This means that the uncertainty in the total global reference irradiance due to uncertainty in the diffuse reference irradiance is on the order of $\pm(0.3 \%$ of the total reference irradiance, +0.3 $\mathrm{Wm}^{-2}$ ). 
Modifications to the ASTM pyrheliometer calibration standard removed the requirement to subtract "dark readings" for the pyrheliometers under test at the beginning and end of the calibration sequence. This is because of the demonstrated unstable nature of the pyrheliometer offset described in the previous section. Improved uncertainty and precision and bias sections of all three standards were written based on inter-laboratory and intra-laboratory tests conducted at NREL and other laboratories, and over time within NREL (repeated calibrations of instruments).

Revisions to the E824 standard on comparison techniques were primarily in the area of updated bias, precision, and uncertainty sections, as well as an improved bibliography of recent research in solar radiometer calibrations. Results of the committee ballot will be discussed at the January 2006 ASTM committee G03 meeting in Ft. Lauderdale, FL.

\subsection{Upgrade of NREL Radiometer Calibration System}

One source of error in Tables 3.3 and 3.4 that could be reduced is the data logger bias of 9 microvolts. This is because the specifications of the data logger used in our RCC system for the past 5 years quote, and NREL has verified, this offset error. In addition, the old data logger (Fluke Helios) is obsolete - more than 7 years old - and no longer supported by John Fluke Co. To reduce this source of uncertainty and improve reliability and maintainability of our system, a DataProof low thermal voltage scanner, shown in Figure 3.14, was chosen. In the first half of FY 2005, we assembled a data logging system consisting of the low offset switches, high quality off-the-shelf voltage measuring systems, and NREL-designed computer controlled data acquisition. Figure 3.15 shows the assembled RCC data acquisition system configured for testing.
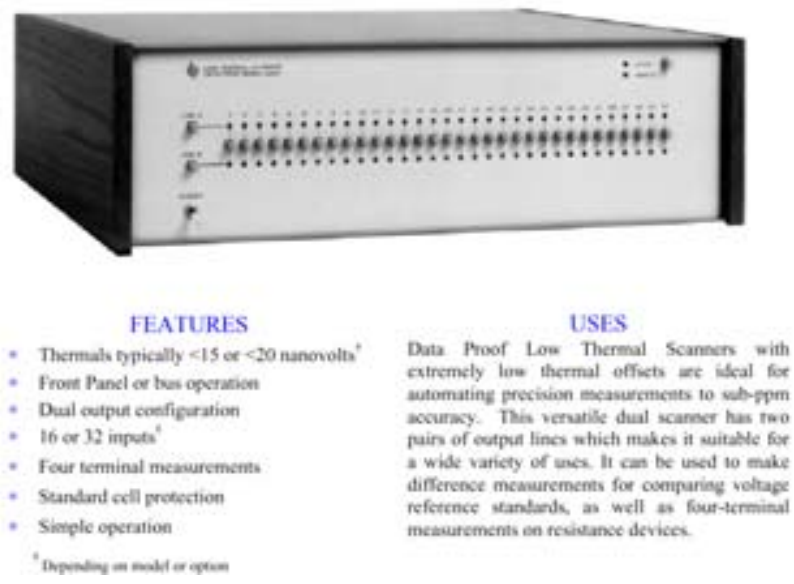

Figure 3.14 DataProof low thermal voltage scanner, which is the basis of the new RCC data collection system. Note low voltage bias of less than 1.0 microvolts. 


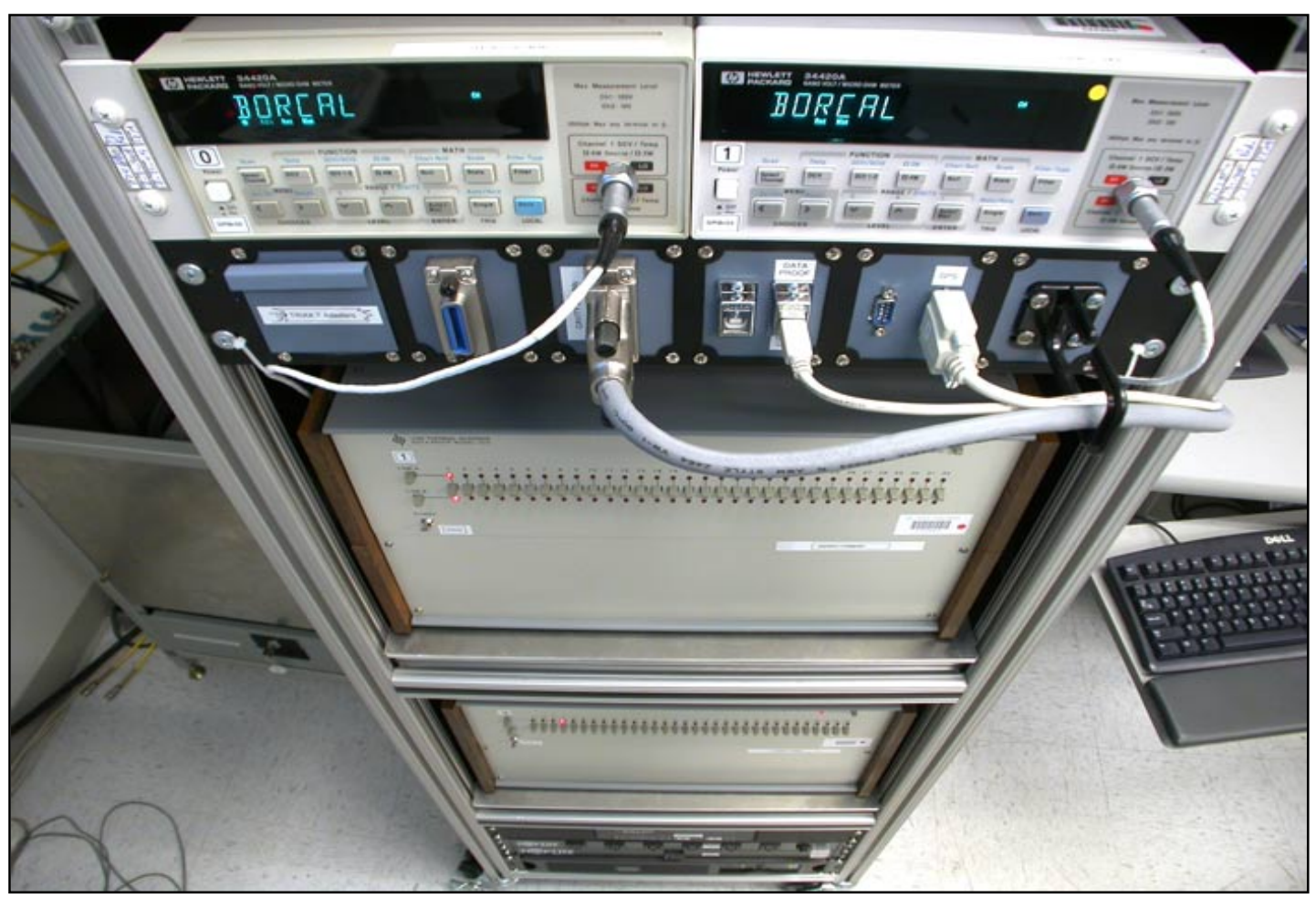

Figure 3.15 New 100 channel custom NREL RCC high quality voltage measurement system configured for operational testing and control software development.

Initial tests show short circuit (zero) voltage bias errors of less than 1.0 microvolt for the new system, which is a factor of 9 improvement over the older system. Further testing was conducted to evaluate and select the best configuration and software algorithms for collecting radiometer calibration data. RCC software was upgraded to include this data logger as a selectable instrument for collecting the calibration data. During FY 2005 the last two NREL BORCAL events (BORCAL 2005-03 and BORCAL 2005-04, respectively) were conducted with the old (Fluke Helios) and new (DataProof) data acquisition systems. The results from the two events were compared to evaluate any new biases appearing due to the new system configuration.

Thirty instruments were common to the two BORCAL events, and the events were conducted within one week of each other to avoid biases introduced by changing environmental conditions and solar geometry. Figure 3.16 shows the percent deviation in responsivity for the 30 instruments is less than $0.4 \%$, and the average deviation was $0.11 \%$. Some of this deviation is due to different environmental conditions and solar geometry, however, and is comparable with the uncertainty in the reference irradiance (derived from the absolute cavity radiometer) of $0.35 \%$. Thus both systems result in essentially the same responsivity results. The improvement with the new system is that the source of uncertainty in the data logger due to the zero offset bias is reduced from $0.1 \%$ to $0.01 \%$, essentially removing this source of error from the uncertainty budget. The resulting expanded uncertainty in each individual responsivity computation is reduced from $1.8 \%$ to $1.6 \%$. 


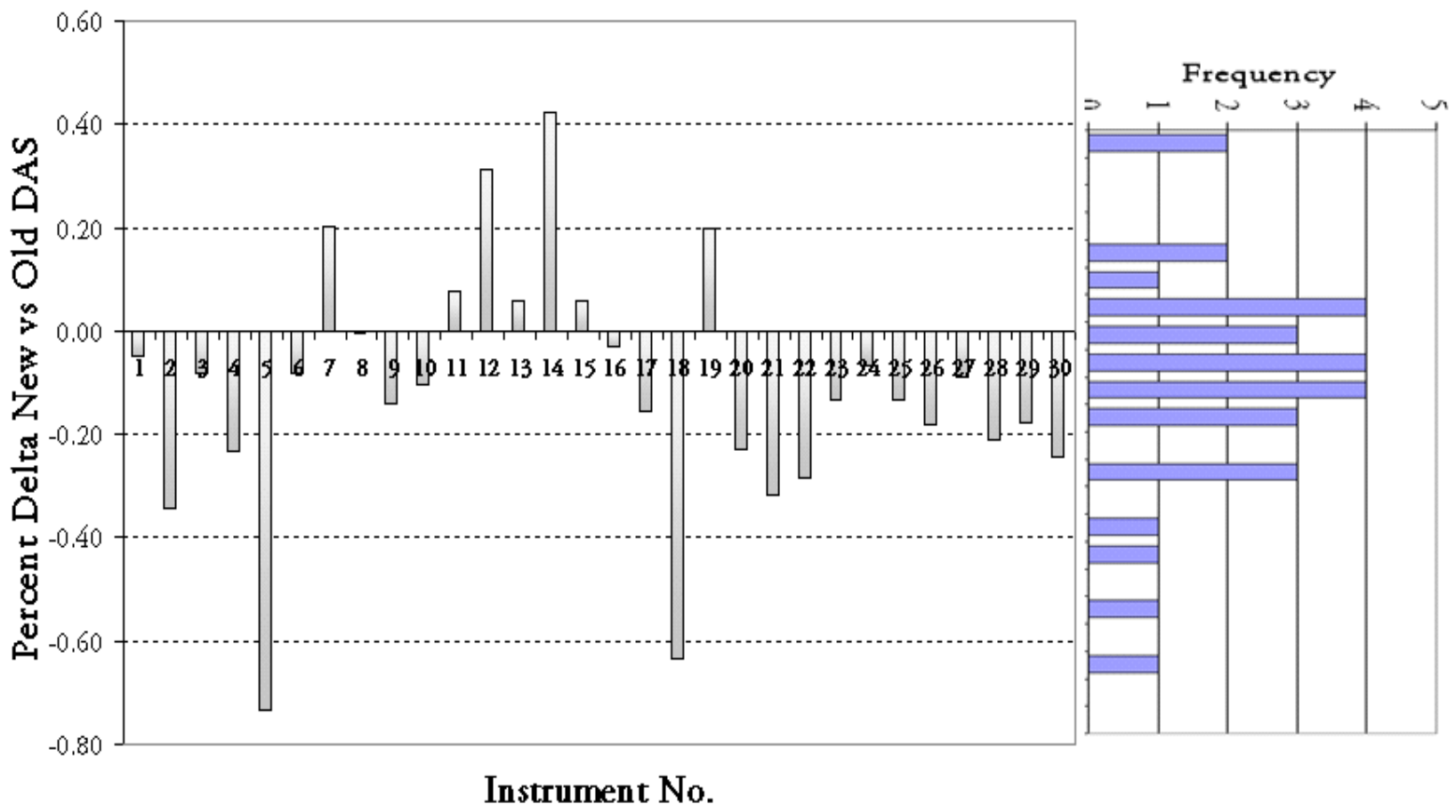

Figure 3.16 Individual deviations in responsivity (in percent) between new and old data acquisition system results for NREL radiometer calibrations. Distribution of differences shown in histogram along right vertical axis.

\subsection{Evaluation of Indoor Calibration System (ICS) for Pyranometers}

For the past two decades, the Solar Radiation Research Laboratory (SRRL) has been calibrating radiometers for use in outdoor solar radiation measurements. Radiometers are calibrated using the NREL-developed BORCAL system. Calibration provides each instrument with an individual solar irradiance sensitivity, which is used to accurately measure solar energy with a traceability to world solar radiation standards. Recently, the SRRL obtained an ICS to provide a flexible alternative to BORCAL during incompatible weather conditions. The ICS was developed by Kipp and Zonen (K\&Z), a solar and atmospheric science instrument manufacturer, for use with their radiometers. We developed a project for one of the co-authors, Amy Bowen of Baylor University, a DOE Summer Undergraduate Laboratory Intern (SULI) to validate the system for calibration of other manufacturer's radiometers. This section of the report is based on her final paper describing the results of the project. Since SRRL calibrations from the BORCAL method are traceable to the WRR, the standard for meteorological radiation measurements, the ICS results must be compared with the BORCAL results to ensure that they meet these international standards. 
Eighteen radiometers populated the study instrument group: one pyrgeometer and 17 pyranometers. Of the pyranometers, there were ten Eppley Precision Spectral Pyranometers (PSP) and seven Licor Li200s. From this group, a total of five reference instruments were employed, three for the Eppley instrument group and two for the Licor instrument group. For both instrument groupings, one reference was chosen at random and, after analyzing preliminary results, a second instrument was selected that most closely matched the average percent difference between the BORCAL and ICS results at a 45-degree zenith angle. An additional PSP reference instrument was chosen after we recognized a bias in the initial selection. The final chosen reference instruments were PSP 18078F3 and Li200 PY28258.

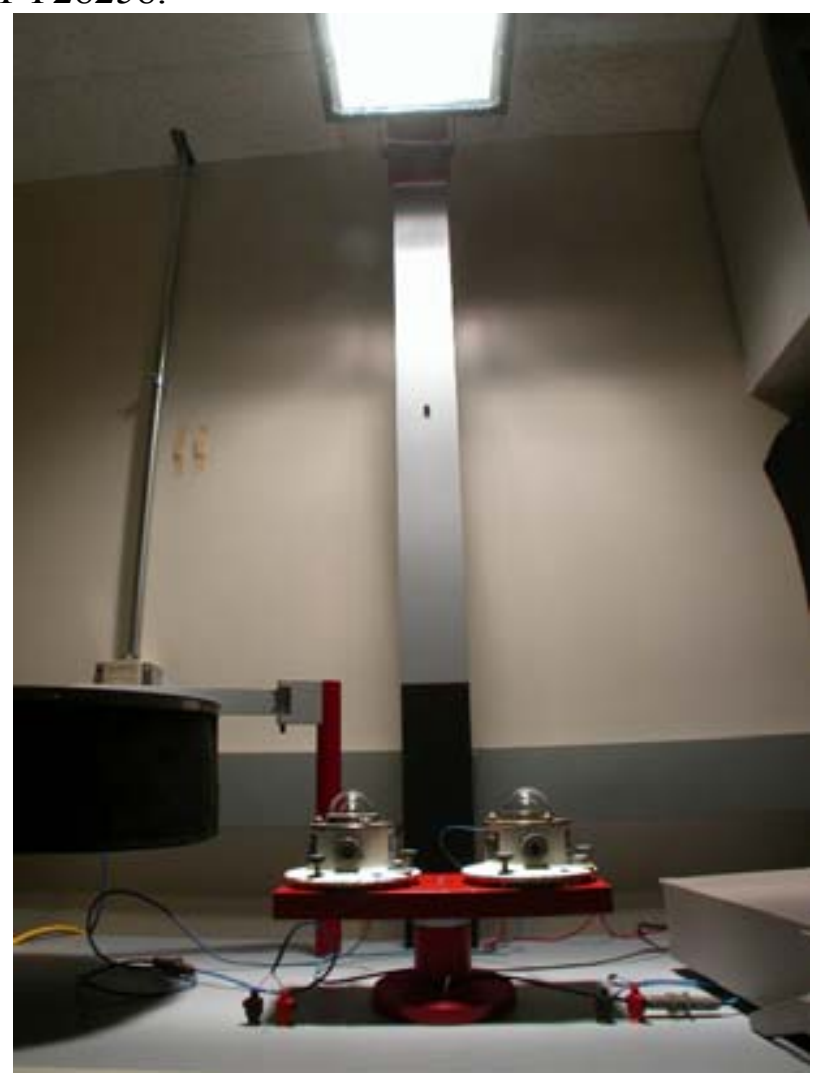

Figure 3.17. The ICS with test and reference instruments installed on the turntable.

The ICS consists of a light source, a turntable for the instrument mounts, a shading mechanism, a voltmeter, and a voltage stabilizer, all of which are mounted on a worktable (Figure 3.17).

The light source is mounted on a post attached to the back and center of the table. The turntable rests on the table directly below the lamp. A rotating arm supports the shading mechanism, which consists of a black cloth cylinder draped from a solid, circular ceiling. At the base of the turntable is a switch for toggling the voltmeter connection between the reference and test instruments. Since the original instrument mount was designed for Kipp and Zonen pyranometers, two new mounts were made to accommodate the Eppley and Licor instruments. 
Interactive software was developed using the LabWindows integrated development environment, to aid the user in the ICS data acquisition process. The program prompts the user through the procedure, indicating when to shade, un-shade, rotate the instruments, and flip the voltmeter switch. The user is required to register each reference instrument by entering its information; the reference can then be selected from a pull-down menu of pre configured reference instruments. The data are displayed in a table as measurements are gathered from the voltmeter. At the end of the procedure, the software displays the test instrument's sensitivity, the lamp stability, and presents the user with a file saving option.

The testing procedure for one instrument takes approximately seven minutes. First the instruments are placed on the turntable mount and are shaded for two minutes while they stabilize. Next, the instruments are unveiled for a period of one minute before a voltage reading is taken from both. Again, the instruments are shaded, this time for a period of one minute before a voltage reading is taken. This is the "zero" reading for the first position (it is subtracted from the illuminated voltage reading to account for biases). Then the instrument mount is rotated $180^{\circ}$ to the second position and the shade, un-shade procedure is repeated. The sensitivity of the test instrument is computed from the collected voltages and the known sensitivity of the reference instrument. The lamp stability is also computed from the collected voltages, with more than a $0.5 \%$ difference between the two positions considered unacceptable. If the lamp stability is unacceptable, the procedure is repeated for that particular instrument.

Table 3.6 shows measured BORCAL and ICS responsivities and their differences at a 45degree zenith angle with the chosen PSP reference instrument, 18078F3. Two apparent outlier instruments, $25823 \mathrm{~F} 3$ and $25824 \mathrm{~F} 3$, responsivities were respectively $6.41 \%$ and $4.44 \%$ greater than their BORCAL responsivities. With these outliers, the average difference between responsivities for the two different methods was $-1.25 \%$ and the standard deviation was $2.46 \%$. Removing these outliers from statistical analysis, the mean difference was $-0.06 \%$ and the standard deviation of the differences was $0.72 \%$. 
Table 3.6. Comparison of BORCAL Responsivities to ICS PSP Responsivities

\begin{tabular}{|c|c|c|c|}
\hline Instrument & $\begin{array}{c}\text { BORCAL RS } \\
\left(\mu \mathrm{V} / \mathrm{W} / \mathrm{m}^{2}\right) \\
\end{array}$ & $\begin{array}{c}\text { ICS RS } \\
\left(\mu \mathrm{V} / \mathrm{W} / \mathrm{m}^{2}\right)\end{array}$ & $\%$ Difference \\
\hline $30561 \mathrm{F3}$ & 9.06 & 9.08 & -0.27 \\
\hline 17879F3 & 7.82 & 7.82 & 0.08 \\
\hline 17897F3 & 6.93 & 6.91 & 0.26 \\
\hline 19621F3 & 7.73 & 7.66 & 0.91 \\
\hline $25823 F 3$ & 9.29 & 9.86 & -6.13 \\
\hline 20079F3 & 9.31 & 9.37 & -0.66 \\
\hline 29668F3 & 8.22 & 8.18 & 0.48 \\
\hline 25824F3 & 9.69 & 1.01 & -4.67 \\
\hline 18040F3 & 7.98 & 8.07 & -1.21 \\
\hline \multirow{2}{*}{$\begin{array}{l}\text { Outliers } \\
\text { Included }\end{array}$} & \multirow{2}{*}{\multicolumn{2}{|c|}{$\begin{array}{r}\text { Mean } \\
\text { Standard Deviation }\end{array}$}} & -1.25 \\
\hline & & & 2.46 \\
\hline \multirow{2}{*}{$\begin{array}{l}\text { Outliers } \\
\text { Excluded }\end{array}$} & \multirow{2}{*}{\multicolumn{2}{|c|}{$\begin{array}{r}\text { Mean } \\
\text { Standard Deviation }\end{array}$}} & -0.06 \\
\hline & & & 0.72 \\
\hline
\end{tabular}

Table 3.7 shows results for the Licor Li200 instruments with reference instrument PY28258. This set of instruments also contained one outlier, whose indoor responsivity deviated from its BORCAL responsivity by $3.37 \%$. The rest of the instruments' ICS responsivities differed from their BORCAL responsivities by $1.71 \%$ or less.

Table 3.7. Comparison of BORCAL and ICS Li-Cor Responsivities *

\begin{tabular}{|c|c|c|c|}
\hline Instrument & $\begin{array}{c}\text { BORCAL RS } \\
\left(\mu \mathrm{V} / \mathrm{W} / \mathrm{m}^{2}\right) \\
\end{array}$ & $\begin{array}{c}\text { ICS RS } \\
\left(\mu \mathrm{V} / \mathrm{W} / \mathrm{m}^{2}\right)\end{array}$ & $\%$ Difference \\
\hline PY3423 & 8.32 & 8.17 & 1.71 \\
\hline PY28261 & 13.66 & 13.67 & -0.09 \\
\hline PY28254 & 12.40 & 11.98 & 3.37 \\
\hline PY28253 & 11.48 & 11.52 & -0.36 \\
\hline PY28251 & 12.90 & 12.84 & 0.46 \\
\hline PY28252 & 11.95 & 11.80 & 1.25 \\
\hline \multirow{2}{*}{$\begin{array}{l}\text { Outliers } \\
\text { Included }\end{array}$} & & Mean & 1.06 \\
\hline & \multicolumn{2}{|c|}{ Standard Deviation } & 1.38 \\
\hline \multirow{2}{*}{$\begin{array}{l}\text { Outliers } \\
\text { Excluded }\end{array}$} & \multirow{2}{*}{\multicolumn{2}{|c|}{$\begin{array}{r}\text { Mean } \\
\text { Standard Deviation }\end{array}$}} & 0.60 \\
\hline & & & 0.88 \\
\hline
\end{tabular}

*at 45-degree zenith angle using Li200 reference instrument PY28258. RS = Responsivity in $\mu \mathrm{V} / \mathrm{W} / \mathrm{m}^{2}$. Shaded boxes indicate outliers.

The total uncertainty for the ICS was determined based on the individual uncertainties of the following: the multimeter (Keithley model 2000), the spectral mismatch error, the stability of the lamp and the reference instruments' stabilities and BORCAL responsivities. 
The largest contributor to the system uncertainty was the spectral mismatch error. Figure 3.18 shows the spectral irradiance difference between outdoor and indoor sources.

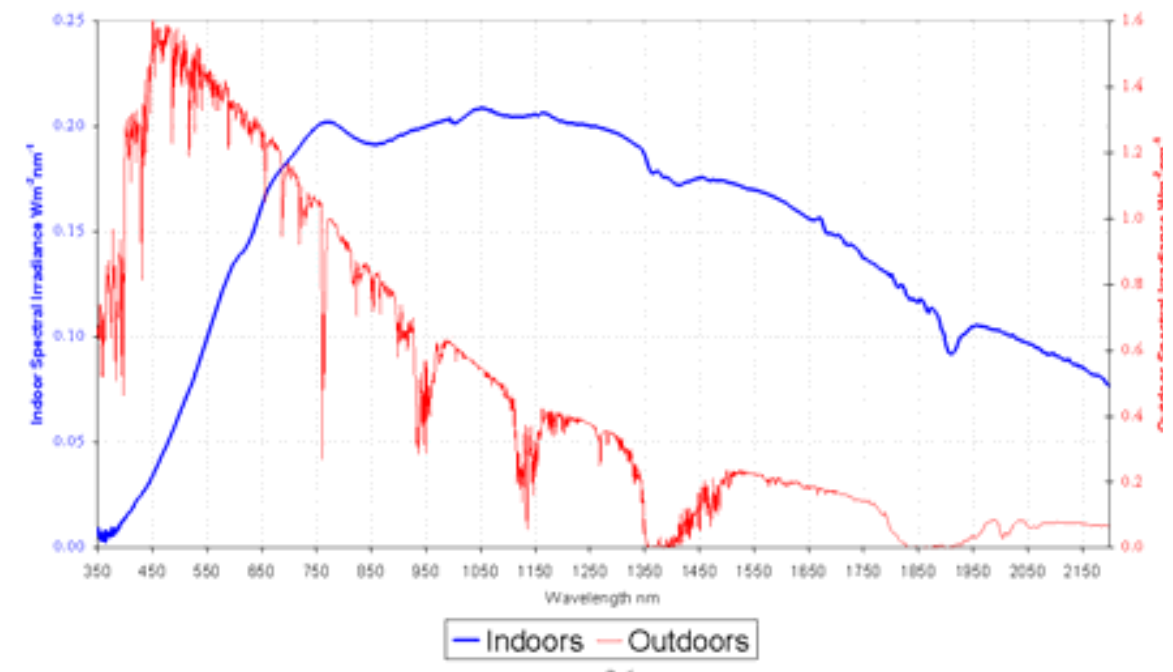

Figure 3.18. Spectral distribution of natural sunlight and ICS lamp source.

Considering all PSP's, we found there is a $4 \%$ difference in the way that the instruments respond to the indoor spectrum verses the outdoor spectrum. Most of this difference is attributed to the outlier instruments; therefore, if subsequent research allows us to confidently exclude those instruments from our results, this spectral uncertainty would be reduced to $0.5 \%$. A total theoretical uncertainty of $4.41 \%$ was calculated for the larger spectral mismatch error and $1.93 \%$ uncertainty was calculated for the smaller error. These uncertainty calculations were supported by our experimental uncertainty, which was calculated to be $5.08 \%$, or $1.44 \%$ if the outlier instruments are excluded.

After identifying the two PSP outlier instruments we noticed their adjacent serial numbers (25823F3 and 25824F3). This led us to hypothesize a physical difference in this particular set of instruments, possibly related to manufacturing or past use, that causes them to behave differently than the others. Refer to Table 3.6; notice the comparatively large gap between the BORCAL and ICS data points for these two instruments. To investigate, we took these two outliers and one of our reference instruments outdoors and repeatedly took voltage readings from each during a 20-minute period. After applying the BORCAL responsivities, both instruments followed the reference instrument's response to within $0.5 \%$. This validated the BORCAL results for outdoor irradiance. Next, we took another instrument from the same serial number range (PSP 25825F3) and calculated its responsivity using the ICS, where we found it to have a $4.91 \%$ higher ICS than BORCAL responsivity.

In the third experiment, we took voltage readings from both of the outliers and the reference instruments after positioning an infrared absorbing filter between the instrument dome and the lamp. Both outlier instruments' responsivities decreased by several $\mu \mathrm{V} / \mathrm{W} / \mathrm{m}^{2}$ when filtered, while the reference instruments' responsivities either 
slightly increased or showed no change. This response suggests that the outlier instruments are more responsive in the infrared region than the other instruments tested.

Considering that the natural sunlight and lamp spectra are very different, and the two outliers respond differently in some areas of the spectrum than the other instruments do, we conclude the outlier ICS responsivities do not match their BORCAL responsivities due to this spectral mismatch. These experiments suggested a material difference between the outliers and the other instruments that we were testing, possibly a different or inconsistent paint or seal on the sensor of the instruments. Further investigation into the cause of the unusual behavior of these instruments must be performed before the ICS can be sufficiently validated and so that "problem" instruments can be identified prior to or as a result of the calibration. 


\subsection{Upgrades to the Measurement and Instrumentation Team Website}

The Solar Radiometry and Metrology task partially supports the SRRL Measurement and Instrumentation Team (MIT) website. On April 8, 2005, the site became one of the few examples in the world where continuous solar radiation data has been collected for 25 years. All 25 years of the collected data are available and can be downloaded from the site at http://www.nrel.gov/midc/.

Twelve measurement stations, including the SRRL BMS site, are available through this page. The BMS site provides access to 138 different measurement parameters, all of interest to the solar radiation research community. Until recently, data could be downloaded as either:

- Daily data: ASCII or compressed data selected for a single day, or period, at the data time resolution ( 5 minute or 1 minute data).

or

- Hourly monthly summary data for the MIDC Solar Radiation Monitoring stations.

The option to generate hourly data (by averaging the 1 or 5 minute raw data) is now available for any MIDC station. A new option to generate "Selected Hourly Data (ASCII)" and "Selected Hourly Data (ZIP)" is now available from the "Daily Data/Plots" page on the MIDC. The user can then select any day range and instruments. The "hourly data" was previously only available for SRRL BMS (using the QA'd monthly data from DQMS). Now it can be done for any site using the raw data.

This capability will permit much more efficient use of the measured data for producing system performance solar radiation input file structures, verification and validation of hourly solar radiation models, data for producing Typical Meteorological Year file structures, and many other applications.

In addition to the interface and data access modifications above, several instruments were decommissioned, refurbished, or upgraded during the year. The degradation of filters in the EKO Model MS 110 sunphotometer required decommissioning that unit until funds become available for new replacement filters (approximately \$5,500 US).

We disassembled the Atmospheric Optical Calibration system, and NREL-developed sunphotometer, and evaluated the filters used in that unit. Transmission measurements showed little degradation, however as spare, unused filters were available, new filters were installed in the unit. At the same time, we developed the ability to display and analyze Langley plots to calibrate the sunphotometer channels on clear days. Figure 4.1 is an example AOCS Langley plot (from which instrument channel calibration coefficients can be derived). 


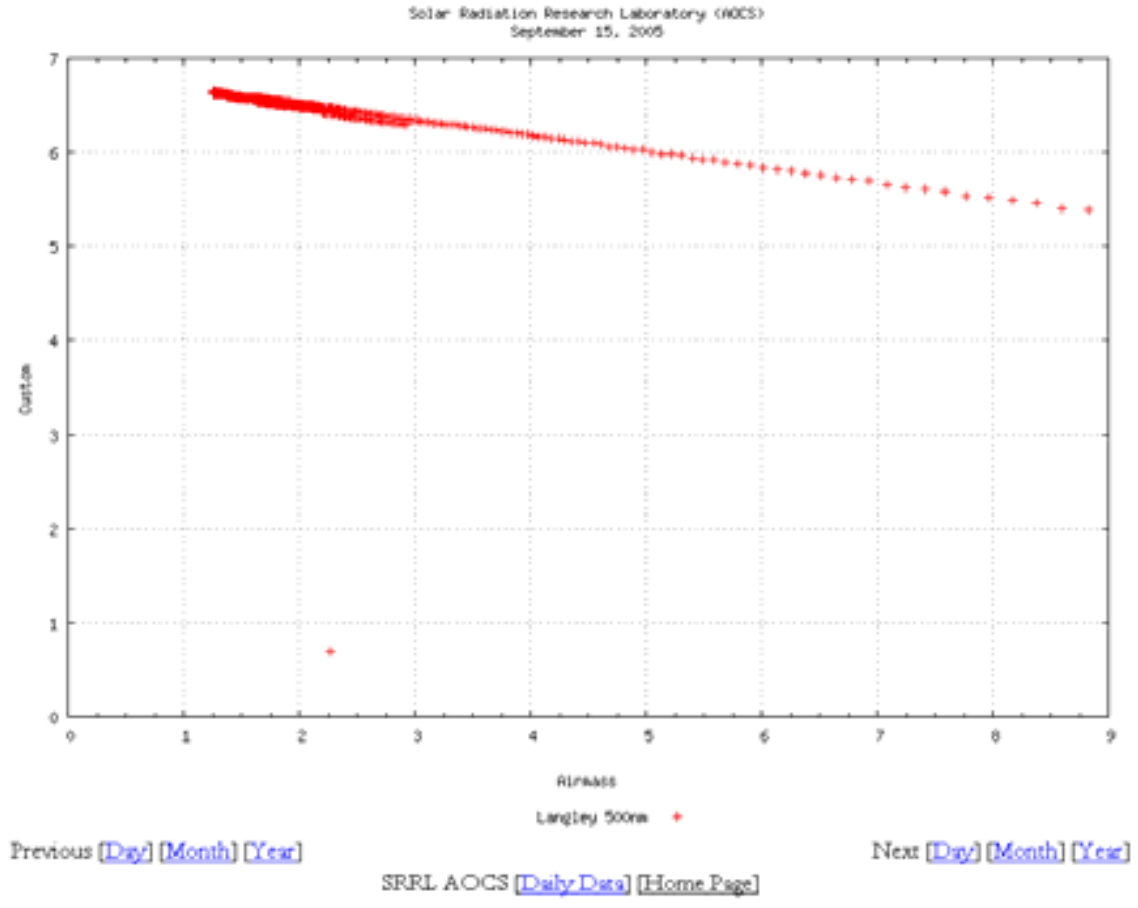

Figure 4.1 Daily clear sky Langley (sunphotometer calibration) plots for narrow band channels of Atmospheric Optical Calibration System now available at Measurement and Instrumentation Data Center (MIDC) website. 500 nm channel shown for September 17, 2005. 


\subsection{Solar Radiometric Metrology Interactions-Second Half of FY 2005}

The table below is a sample of an additional 95 interactions documented with the PV industry, academia, and other national and international laboratories over and above the 135 interactions in the first half of FY 2005 summarized in section 5.0 of the midyear report.

Table 5.1 Industrial, Academic, National and International Laboratory Interactions

\begin{tabular}{|c|c|c|}
\hline Contact & $\begin{array}{c}\text { Topic } \\
\end{array}$ & Outcome \\
\hline $\begin{array}{l}\text { Spire Corporation } \\
\text { Bedford, MA } \\
\text { Jun } 1\end{array}$ & $\begin{array}{l}\text { Information on spectroradiometer } \\
\text { design and performance }\end{array}$ & $\begin{array}{l}\text { Provided overview, } \\
\text { experience concerning } \\
\text { various types of } \\
\text { spectrometers. }\end{array}$ \\
\hline $\begin{array}{c}\text { HelioTrax } \\
\text { San Diego CA } \\
\text { Jun } 2 \\
\end{array}$ & $\begin{array}{l}\text { Bird Clear sky model filtering of } \\
\text { data for various geometries }\end{array}$ & $\begin{array}{l}\text { Provided technical } \\
\text { guidance on filtering data } \\
\text { for daylight applications }\end{array}$ \\
\hline $\begin{array}{c}\text { Honeywell Specialty Films } \\
\text { Morris Township NJ } \\
\text { Jun } 6\end{array}$ & $\begin{array}{l}\text { Reflectance measurements tedlar } \\
\text { films }\end{array}$ & $\begin{array}{l}\text { Provided measurements } \\
\text { requested. }\end{array}$ \\
\hline $\begin{array}{c}\text { Universidad de Valladolid } \\
\text { Departamento de Física } \\
\text { Aplicada } \\
\text { Facultad de Ciencias } \\
\text { Valladolid Spain } \\
\text { Jun } 6\end{array}$ & $\begin{array}{l}\text { Use of SMARTS model For UV } \\
\text { spectral estimation }\end{array}$ & $\begin{array}{l}\text { Provided links to model } \\
\text { and documentation, } \\
\text { literature references. }\end{array}$ \\
\hline $\begin{array}{c}\text { Mangosuthu Technikon } \\
\text { Institute of Technology } \\
\text { Durban South Africa } \\
\text { Aug } 5\end{array}$ & $\begin{array}{l}\text { Information on solar radiation } \\
\text { instrumentation selection, site, } \\
\text { setup, and maintenance }\end{array}$ & $\begin{array}{l}\text { Provided CD of reference } \\
\text { documents. }\end{array}$ \\
\hline $\begin{array}{c}\text { DOE Headquarters } \\
\text { Solar Energy Technologies } \\
\text { Program } \\
\text { Washington, D.C. } \\
\text { Aug } 26\end{array}$ & $\begin{array}{l}\text { Web site inquiry; conversion of } \\
\text { irradiance to photon flux density } \\
\text { in visible range }\end{array}$ & $\begin{array}{l}\text { Provided sample } \\
\text { calculation and } \\
\text { conversion factor }\end{array}$ \\
\hline $\begin{array}{l}\text { Pacific Northwest } \\
\text { Laboratories } \\
\text { Richland WA } \\
\text { Jun BORCAL }\end{array}$ & $\begin{array}{l}\text { Pyranometer and Pyrheliometer } \\
\text { calibration and characterization }\end{array}$ & $\begin{array}{l}\text { ISO } 17025 \text { compliant } \\
\text { calibration results }\end{array}$ \\
\hline $\begin{array}{c}\text { DuPont Displays } \\
\text { Santa Barbara CA } \\
\text { Aug } 15\end{array}$ & $\begin{array}{l}\text { Solar daylight modeling for } \\
\text { outdoor display glare research }\end{array}$ & $\begin{array}{l}\text { CIE, ASTM, NIST and } \\
\text { SMARTS model } \\
\text { generation of CIE D65 } \\
\text { illuminant information } \\
\text { discussed over several } \\
\text { exchanges. }\end{array}$ \\
\hline $\begin{array}{c}\text { NASA } \\
\text { Surface Solar Energy Working } \\
\text { group } \\
\text { Aug } 252005 \text { (ASES } \\
\text { Conference) }\end{array}$ & $\begin{array}{l}\text { Paper on model performance } \\
\text { bias and random error analysis }\end{array}$ & $\begin{array}{l}\text { Model performance US } \\
\text { Solar Radiation Data } \\
\text { Base upgrade }\end{array}$ \\
\hline
\end{tabular}




\begin{tabular}{|c|c|c|}
\hline Contact & $\begin{array}{c}\text { Topic } \\
\end{array}$ & Outcome \\
\hline $\begin{array}{c}\text { National Institute of } \\
\text { Standards and Technology } \\
\text { Gaithersburg MD } \\
\text { August } 29\end{array}$ & $\begin{array}{l}\text { Request for Pyranometer and } \\
\text { pyrheliometer calibrations. }\end{array}$ & $\begin{array}{l}\text { Provided logistical and } \\
\text { technical information for } \\
\text { next BORCAL event }\end{array}$ \\
\hline $\begin{array}{c}\text { QF Colorado Springs Utility } \\
\text { Colo. Springs, CO. } \\
\text { Aug } 26\end{array}$ & $\begin{array}{l}\text { Request for flat plat resource } \\
\text { data to correlate with utility peak } \\
\text { load, CO. Springs site. }\end{array}$ & $\begin{array}{l}\text { Provided Info on } \\
\text { PVWATTS and NSRDB } \\
\text { website data sources, } \\
\text { suggested analysis } \\
\text { approach. }\end{array}$ \\
\hline $\begin{array}{c}\text { Obafemi Awolowo University, } \\
\text { lle-Ife, Nigeria. } \\
\text { Jun } 7\end{array}$ & $\begin{array}{l}\text { Information on filters for UV } \\
\text { exposure testing }\end{array}$ & $\begin{array}{l}\text { Technical references } \\
\text { provided. }\end{array}$ \\
\hline $\begin{array}{c}\text { Photovoltaic and Thermal } \\
\text { Energy } \\
\text { Solar Outdoor Laboratory } \\
\text { St Paul lez Durance Cedex, } \\
\text { France } \\
\text { Jun } 17\end{array}$ & $\begin{array}{l}\text { Means to calculate annual } \\
\text { average spectral distribution and } \\
\text { photon flux density in PV } \\
\text { response bands }\end{array}$ & $\begin{array}{l}\text { SMARTS spectral model } \\
\text { discussed and example } \\
\text { calculations provided. }\end{array}$ \\
\hline $\begin{array}{c}\text { National Institute of } \\
\text { Standards and Technology } \\
\text { Gaithersburg MD } \\
\text { July } 17 \\
\end{array}$ & $\begin{array}{l}\text { Information on techniques for } \\
\text { measuring spectral distributions } \\
\text { pulse simulators }\end{array}$ & $\begin{array}{l}\text { Provided logistical and } \\
\text { technical information on } \\
\text { NREL PASS system }\end{array}$ \\
\hline $\begin{array}{c}\text { National Institute of } \\
\text { Oceanography } \\
\text { Goa, India } \\
\text { Sep } 2\end{array}$ & $\begin{array}{l}\text { Extraterrestrial spectral } \\
\text { distributions appropriate for use } \\
\text { in estimating ocean color from } \\
\text { satellite data }\end{array}$ & $\begin{array}{l}\text { Provided links to NREL } \\
\text { and other web sites with } \\
\text { ETR spectra }\end{array}$ \\
\hline $\begin{array}{c}\text { Department Solar Cells- } \\
\text { Materials and Technology } \\
\text { Fraunhofer-Institut für Solare } \\
\text { Energiesysteme ISE } \\
\text { Freiburg, Germany } \\
\text { Sep } 15 \\
\end{array}$ & $\begin{array}{l}\text { Spectral modeling code and } \\
\text { applications to PV performance } \\
\text { evaluation, prediction }\end{array}$ & $\begin{array}{l}\text { Description of application } \\
\text { of SMARTS code, URL } \\
\text { for inventory of spectral } \\
\text { modeling codes available. }\end{array}$ \\
\hline $\begin{array}{c}\text { ConEdison NJ } \\
\text { Aug } 16 \\
\end{array}$ & $\begin{array}{l}\text { Resource data for flat plate and } \\
\text { concentrator systems in } \mathrm{NJ}\end{array}$ & $\begin{array}{l}\text { Provided NSRDB data } \\
\text { and analysis approach }\end{array}$ \\
\hline $\begin{array}{l}\text { Dow Chemical Co. } \\
\text { Freeport Tx. } \\
\text { Sep } 5 \\
\end{array}$ & $\begin{array}{l}\text { Modeling solar irradiance on } \\
\text { cylindrical chemical storage tank }\end{array}$ & $\begin{array}{l}\text { Provided references and } \\
\text { simple computational } \\
\text { model }\end{array}$ \\
\hline $\begin{array}{c}\text { H2GO } \\
\text { Saratoga CA } \\
\text { Sep } 17 \\
\end{array}$ & Cavity radiometer information & $\begin{array}{l}\text { Referred to inventor and } \\
\text { manufacturer of } \\
\text { instrument }\end{array}$ \\
\hline $\begin{array}{c}\text { Arizona Public Service } \\
\text { Phoenix, AZ } \\
\text { Jun BORCAL }\end{array}$ & $\begin{array}{l}\text { Radiometer Calibrations (UV } \\
\text { radiometers, Pyranometer, } \\
\text { pyrheliometers) }\end{array}$ & $\begin{array}{l}\text { ISO } 17025 \text { compliant } \\
\text { radiometer calibrations } \\
\text { supporting accreditation }\end{array}$ \\
\hline $\begin{array}{c}\text { National Institute of } \\
\text { Standards and Technology } \\
\text { Gaithersburg MD } \\
\text { August } 24 \text { (ASES conference) } \\
\end{array}$ & $\begin{array}{l}\text { Pyranometer Thermal Offset data } \\
\text { and corrections. }\end{array}$ & $\begin{array}{l}\text { Shared experimental } \\
\text { data, draft publications, } \\
\text { and references. }\end{array}$ \\
\hline $\begin{array}{c}\text { Kipp And Zonen } \\
\text { Delft Netherland and Bohemia } \\
\text { New York } \\
\text { Sep } 27\end{array}$ & $\begin{array}{l}\text { Uncertainty sources and } \\
\text { applications for thermopile versus } \\
\text { silicon pyranometers }\end{array}$ & $\begin{array}{l}\text { Information on silicon cell } \\
\text { pyranometer corrections } \\
\text { and uncertainty for PV } \\
\text { monitoring applications } \\
\text { versus climate change } \\
\text { data }\end{array}$ \\
\hline
\end{tabular}




\begin{tabular}{|c|l|l|}
\hline Contact & \multicolumn{1}{|c|}{ Topic } & \multicolumn{1}{c|}{ Outcome } \\
\hline $\begin{array}{c}\text { Florida Solar Energy Center } \\
\text { Cocoa, FL } \\
\text { Feb 24 }\end{array}$ & Pyranometer calibration issues & $\begin{array}{l}\text { Shared example } \\
\text { calibration results, } \\
\text { consensus on data } \\
\text { processing techniques } \\
\text { and sources of } \\
\text { differences }\end{array}$ \\
\hline $\begin{array}{c}\text { Shell Solar } \\
\text { Camarillo, CA (Feb 05) }\end{array}$ & $\begin{array}{l}\text { Pulse spectral simulator } \\
\text { accuracy in PV product } \\
\text { testing, }\end{array}$ \\
\hline $\begin{array}{c}\text { SPIRE Corp. } \\
\text { Bedford, MA } \\
\text { Sep 16 }\end{array}$ & $\begin{array}{l}\text { Request to measure spectral } \\
\text { distribution of 2 model 350i and } \\
\text { one prototype Solar Simulator }\end{array}$ & $\begin{array}{l}\text { ISO 17025 compliant } \\
\text { ASTM E927 } \\
\text { classifications }\end{array}$ \\
\hline \multicolumn{2}{|l}{}
\end{tabular}




\subsection{Major Publications}

ASTM Standards G167-00 Standard Test Method for Calibration of a Pyranometer Using a Pyrheliometer (REVISION)

ASTM Standard E816-95 Standard Test Method for Calibration of Pyrheliometers by Comparison to Reference (REVISION)

ASTM Standard E824-94 Standard Test Method for Transfer of Calibration from Reference to Field Radiometers. (REVISION)

Lester, A., D. R. Myers, A Method for Improving Global Pyranometer Measurements by Modeling Responsivity Functions. Solar Energy, 2005. In Press

Reda, I., J. Hickey, C. Long, D. Myers, T. Stoffel, S. Wilcox, J.J. Michalsky, E.G. Dutton, D. Nelson, Using a Blackbody to Calculate Net-Longwave Responsivity of Shortwave Solar Pyranometers to Correct for Their Thermal Offset Error During Outdoor Calibration Using the Component Sum Method. Journal of Atmospheric and Oceanic Technology, Vol. 22, No. 10, pages 1531-1540,2005.

Myers, et al. FY 2005 Midyear Progress Report Solar Radiometry and Metrology Task PVC57301 NREL/TP-56-37954 March 2005.

Stoffel et al, "NREL Participation in the DOE Atmospheric Radiation Measurement (ARM) Program" CORM 2004 Annual Technical Conference NIST Boulder CO May 11-13 2005.

Reda, et al., "Determination of Longwave Response of Shortwave Solar Radiometers" CORM 2004 Annual Technical Conference NIST Boulder CO May 11-13 2005.

Myers, et al., "Solar Radiometric Metrology for Renewable Energy Applications" CORM 2004 Annual Technical Conference NIST Boulder CO May 11-13 2005.

Myers, et al., "An Update on Reducing the Uncertainty in Solar Radiometric Measurements", in Proceedings Solaris 2005 2nd Joint International Conference May 2627, 2005. Athens, Greece.

Myers, D.R., "Solar radiation modeling and measurements for renewable energy applications: data and model quality" Energy, Volume 30, Issue 9, 1 July 2005, Pages 1517-1531 (No. 8 on the list of "top 25 downloaded articles").

Myers, et al., "Analysis of Broadband Model Performance for an Updated National Solar Radiation Database in the United States of America" 2005 Joint ISES/ASES meeting, Orlando FL Aug 6-12 2005. 


\subsection{Conclusion}

A great deal of progress in understanding the sources of uncertainty in broadband radiometer measurements has been accomplished in the period covered by this report. The Solar Radiometric Metrology task has maintained ISO 17025 compliant traceability for solar and optical radiation calibrations and measurements. This includes monitoring the stability of the WRR scale for NREL reference cavity radiometers and maintaining the NIST Scale of Spectral Irradiance. We revisited and revised our analysis of uncertainty for both broadband and spectral measurement systems. We measured and characterized the performance of several NREL research and PV industry solar simulators, providing data essential for translating PV performance measurements to Standard Reporting Conditions. Our research has led to new insights into sources of error in broadband radiometers, and improved methods of correcting for environmental influences on broadband measurement data. Revisions to existing (ASTM) standard procedures for radiometer calibrations have been developed and put before the consensus standards community for approval later in FY 2006. We are upgrading the radiometer calibration data acquisition system to remove a known bias error from our BORCAL and RADCAL system, and have identified a replacement for obsolescent and aging workhorse spectroradiometers essential to primary and secondary PV reference call calibrations. We have documented over 135 separate interactions with the PV industry, academia, other national laboratories, and PV system designers on a wide range of topics, including instrumentation, calibrations, broadband, and spectral modeling, solar radiation resource data, module and systems energy ratings, and indoor and outdoor PV testing methods. Much of the above have been documented in a series of journal articles and conference papers, disseminating our research results to both the scientific and industrial community. 


\subsection{References}

[1] Myers, D. R., T.L. Stoffel, A.M. Andreas, S.M. Wilcox, I. Reda, M. Anderberg, P. Gotseff, B. Kay, FY 2005 Midyear Progress Report on Solar Radiometry and Metrology Task PVC57301. NREL/TP-560-37954 2005 National Renewable Energy Laboratory

[2] ISO, General requirements for the competence of testing and calibration laboratories. 2005 International Standards Organization, Geneva Switzerland

[3] Anon. International Pyrheliometer Comparison IPC-IX 25 September- 13 October 2000 Results and Symposium. 2001. Davos and Zurich, Switzerland: MeteoSwiss.

[4] ASTM, Standard Test Methods for Electrical Performance of Nonconcentrator Terrestrial Photovoltaic Modules and Arrays Using Reference Cells, Standard E1036. 1998 American Society for Testing and Materials, West Conshohocken, PA.

[5] Walker, J. H., et al., NBS Special Publication 250-20 "Spectral Irradiance Calibrations". 1987 National Institute of Standards and Technology

[6] ANSI, American National Standard for Expressing Uncertainty-U.S. Guide to the Expression of Uncertainty in Measurement. ANSI/NCSL Z540-2-1997 Secretariat, National Conference of Standards Laboratories (NCSL) Boulder, CO. 1997.

[7] BIPM, Guide to the Expression of Uncertainty in Measurement. Published by ISO TAG 4, 1995. International Bureau of Weights and Measures (BIPM) Sevres, France. 1995.

[8] Taylor, B. N., C E Kuyatt, Guidelines for Evaluation and Expressing the Uncertainty of NIST Measurement Results. NIST Technical Note 12971993 National Institute of Standards and Technology

[9] ASTM, Standard Specification for Solar Simulation for terrestrial Photovoltaic Testing ASTM Standard E-927. 1997 American Society for Testing and Materials, West Conshohocken, PA.

[10] Myers, D. R., I. Reda, S. Wilcox, A. Andreas,. Optical Radiation Measurements for Photovoltaic Applications Instrumentation Uncertainty and Performance. in 50th Annual Conference of the Society of Photo-optical Instrumentation Engineers, Organic Photovoltaics V. 2004. Denver, CO: SPIE Bellingham, Washington.

[11] Myers, D. R., T L Stoffel, S Wilcox, I Reda, A Andreas, Recent Progress in Reducing the Uncertainty in and Improving Pyranometer Calibrations. Journal of Solar Energy Engineering, 2002. 124: p. 44-50.

[12] Reda, I., Improving the Accuracy of Using Pyranometers to Measure Clear Sky Global Irradiance NREL/TP-560-24833. NREL/TP-560-24833 1998 National Renewable Energy Laboratory

[13] Reda, I., D Myers, Calculating the diffuse responsivity of solar pyranometers. NREL/TP-560-26483 1999 National Renewable Energy Laboratory

[14] Reda, I., J. Hickey, C. Long,D. Myers, T. Stoffel, S. Wilcox,J.J. Michalsky, E.G. Dutton, D. Nelson, Using a Blackbody to Calculate Net-Longwave Responsivity of Shortwave Solar Pyranometers to Correct for Their Thermal Offset Error During Outdoor Calibration Using the Component Sum Method. Journal of Atmospheric and Oceanic Technology, 2005. 22 (10), pp1531-1540.

[15] Reda, I., T. Stoffel, D. Myers, A Method to calibrate a solar pyranometer for measuring reference diffuse irradiance. Solar Energy, 2003. 74: p. p. 103-112. 
[16] WMO, OMM No. 8 Guide to Meteorological Instruments and Methods of Observation.5th ed. Vol. 8. 1983, Geneva, Switzerland: . Secretariat of the World Meteorological Organization.

[17] WMO, International Pyrheliometer Comparison VIII. Working Report No 1881996 World Meteorological Organization

[18] Reda, I., T Stoffel, D Myers, Calibration of a solar absolute cavity radiometer with traceability to the world radiometric reference. NREL/TP-463-20619 1996 National Renewable Energy Laboratory

[19] ASTM, Standard Test Method for Calibration of a Pyrheliometers by Comparison to Reference Pyrheliometers ASTM E 816-95. ASTM G167-00 2000 American Society for Testing and Materials

[20] ASTM, Standard Test Method for Calibration of a Pyranometer Using a PyrheliometerASTM G167-0. ASTM G167-00 2000 American Society for Testing and Materials

[21] Dutton, E. G., J. J. Michalsky, T. Stoffel, B. W. Forgan, J. Hickey, T. L. Alberta, I. Reda, Measurement of Broadband Diffuse Solar Irradiance Using Current Commercial Instrumentation with a Correction for Thermal Offset Errors. Journal of Atmospheric and Oceanic Technology, 2001. 18(3): p. 297-314.

[22] Gulbrandsen, A., On the Use of Pyranometers in the Study of Spectral Solar Radiation and Atmospheric Aerosols. Journal of Applied Meteorology, 1978. 17: p. 899-904.

[23] Haeffelin, M., S. Kato, A.M. Smith, C.K. Rutledge,T.P. Charlock, J.R. Mahan, Determination of the thermal offset of the Eppley Precision Spectral Pyranometer. Applied Optics, 2001. 40(4): p. 472-484.

[24] Anderson, G. P., A. Berk, P. K. Acharya, M. W. Matthew, L. S. Bernstein, J. H. Chetwynd, Jr., H. Dothe, S. M. Adler-Golden, A. J. Ratkowski, G. W. Felde, J. A. Gardner, M. L. Hoke, S. C. Richtsmeier, B. Pukall, J. B. Mello, and L. S. Jeong. MODTRAN4: radiative transfer modeling for remote sensing. in Optics in Atmospheric Propagation and Adaptive Systems III;. 1999: Society of PhotoOptical Instrumentation Engineers Bellingham, WA.

[25] ASTM, Standard Test Method for Determination of the Spectral Mismatch Parameter Between a Photovoltaic Device and a Photovoltaic Reference Cell ASTM Standard E973M-96 American Society for Testing and Materials, West Conshohocken PA. 1996

[26] Lester, A., D. Myers, A Method for Improving Global Pyranometer Measurements by Modeling Responsivity Functions. Solar Energy, 2005. In Press.

[27] ISO, ISO 98461993: Solar Energy--Calibration of a Pyranometer using a Pyrheliometer. International Standards Organization, Geneva, Swizterland. 1993

[28] Natrella, M. G., Experimental Statistics. National Bureau of Standards Handbook 91. Vol. 91. 1963, Washington, D.C.: National Bureau of Standards. 


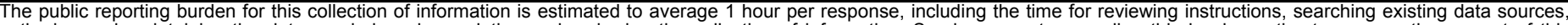

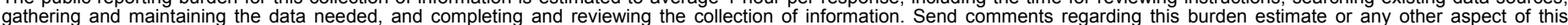

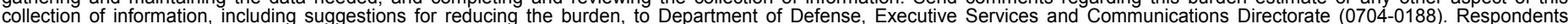

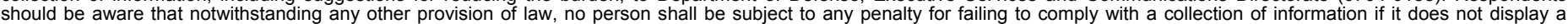

should be aware that notwithstanding

PLEASE DO NOT RETURN YOUR FORM TO THE ABOVE ORGANIZATION.

\begin{tabular}{l|l|l|l} 
1. REPORT DATE $(D D-M M-Y Y Y Y)$ & 2. & REPORT TYPE & 3. DATES COVERED (FrOm - TO)
\end{tabular}

November 2005

Technical Report

4. TITLE AND SUBTITLE

FY 2005 Final Report: Solar Radiometry and Metrology Task

PVC57301 5a. CONTRACT NUMBER

DE-AC36-99-G010337

5b. GRANT NUMBER

5c. PROGRAM ELEMENT NUMBER

5d. PROJECT NUMBER

NREL/TP-560-38917

5e. TASK NUMBER

PVC57301

5f. WORK UNIT NUMBER
7. PERFORMING ORGANIZATION NAME(S) AND ADDRESS(ES)

National Renewable Energy Laboratory

1617 Cole Blvd.

Golden, CO 80401-3393
8. PERFORMING ORGANIZATION REPORT NUMBER

NREL/TP-560-38917

9. SPONSORING/MONITORING AGENCY NAME(S) AND ADDRESS(ES)

10. SPONSOR/MONITOR'S ACRONYM(S) NREL

11. SPONSORING/MONITORING AGENCY REPORT NUMBER

12. DISTRIBUTION AVAILABILITY STATEMENT

National Technical Information Service

U.S. Department of Commerce

5285 Port Royal Road

Springfield, VA 22161

13. SUPPLEMENTARY NOTES

14. ABSTRACT (Maximum 200 Words)

This report documents technical detail for work performed in the Solar Radiometry and Metrology Task in the period from October 1, 2004 to September 30, 2005.

15. SUBJECT TERMS

solar; radiometry; metrology; Baylor

\begin{tabular}{l}
\hline \multicolumn{3}{|l|}{ 16. SECURITY CLASSIFICATION OF: } \\
\hline \begin{tabular}{l|l|l|} 
a. REPORT & b. ABSTRACT & c. THIS PAGE \\
Unclassified & Unclassified & Unclassified \\
& & \\
\hline
\end{tabular} \\
\hline
\end{tabular}

\begin{tabular}{|c|c|}
\hline $\begin{array}{l}\text { 17. LIMITATION } \\
\text { OF ABSTRACT }\end{array}$ & $\begin{array}{ll}\text { 18. } & \text { NUMBER } \\
\text { OF PAGES }\end{array}$ \\
\hline UL & \\
\hline
\end{tabular}

19a. NAME OF RESPONSIBLE PERSON

19b. TELEPHONE NUMBER (Include area code) 